\title{
Late Pleistocene-Holocene history of a tectonically active segment of the continental margin (Nekor basin, Western Mediterranean, Morocco)
}

\author{
Lafosse M. ${ }^{1,{ }^{*}}$, Gorini C. ${ }^{1}$, Le Roy Patrick ${ }^{2}$, Alonso B. ${ }^{3}$, D'acremont E. ${ }^{1}$, Ercilla G. ${ }^{3}$, \\ Rabineau Marina ${ }^{2}$, Vázquez J.T. ${ }^{4}$, Rabaute A. ${ }^{1}$, Ammar A. ${ }^{5}$
}

${ }^{1}$ Sorbonne Universités, UPMC Univ Paris 06, CNRS, Institut des Sciences de la Terre de Paris (iSTeP), 4 Place Jussieu, 75005, Paris, France

2 CNRS, UMR 6538, LGO, Laboratoire Géosciences Océan, Institut Universitaire Européen de la Mer, Place Copernic, 29280, Plouzané, France

${ }^{3}$ Institut de Ciències del Mar (CSIC), Continental Margins Group, 08003, Barcelona, Spain

${ }^{4}$ Instituto Español de Oceanografía, Centro Oceanográfico de Málaga, Puerto Pesquero s/n, Fuengirola, Málaga, Spain

${ }^{5}$ Faculté des Sciences, Université Mohammed V, Rabat, Morocco

* Corresponding author: M. Lafosse, email address : m.r.lafosse@uu.nl

\begin{abstract}
:
In active basins, tectonics can segment the continental shelf and control its stratigraphic architecture and physiography. Segmentation can explain the local evolution and morphology of the continental shelf because of sea-level variations, local tectonic segmentation and hydrodynamic processes. Here we investigate the tectonically active Morocco continental margin (southern Alboran Sea) using highresolution seismic profiles and multibeam bathymetric data. The active faults bounding the transtensive Nekor basin triggered the segmentation of the shelf into three sectors showing different subsidence rates: a western sector corresponding to an extensive fault relay, a central sector corresponding to the subsiding Al-Hoceima Bay and an eastern sector corresponding to the footwall of the Trougout senestral normal fault. Results show that the staircase morphology of the shelf corresponds to successive submarine terraces at the shelf edge (ST1), mid-shelf (ST2) and inner-shelf (ST3) around $-110 \mathrm{~m},-80 \mathrm{~m}$, and -40 to $-20 \mathrm{~m}$ deep, respectively. The terraces correspond to the top of prograding wedges seaward and are erosive landward. They are correlated with stillstand from the Last Glacial Maximum to the Holocene highstand. Above the terraces, sub-aqueous dune fields are interpreted as degraded and deposited during the post-glacial transgression. In the central sector, typical delta front seafloor undulations on the shelf and crescent shaped bedforms at the head of marine incisions on the upper slope denote a fluvial influence during the Holocene. Seismic stratigraphy analysis revealed the preservation of six seismic units bounded by polygenic regional unconformities (S1, S2, S3, S4 and S5). Based on comparison with other Mediterranean margins, S1 to S5 are attributed to 4th order maximum regressive surface. We discuss the local preservation of the system tracts as a function of the vertical motion and the physiography of this tectonically active domain. This study provides useful clues for future local paleo-seismic analysis and to advance our understanding of sedimentary processes in
\end{abstract}


active areas.

\section{Highlights}

We present new data of the morphology of the Mediterranean Moroccan shelf. Marine terraces are present and correlated to local sea level variations. The active tectonic locally segments the shelf and control the stacking pattern. - The relation between the stacking pattern and the morphology is investigated. We propose a depositional model correlating the morphology and the stratigraphy of the shelf.

Keywords : Seismic stratigraphy, Active tectonic, Pleistocene, Continental shelf, Swath bathymetry, Geomorphology, Western Mediterranean 


\section{Introduction}

Middle to Late Pleistocene eustatic sea-level changes are well documented along Mediterranean continental shelves (e.g. Rabineau et al., 2005; Ridente et al., 2009; Chiocci and Chivas, 2014; Chiocci et al., 1997; Lobo et al., 2014). Previous studies have shown that organization of the strata of the Mediterranean continental shelves in the Quaternary and preservation of the depositional sequences are controlled by the asymmetry and the amplitude (maximum $110 \mathrm{~m} \pm 15$ 
m) of the glacio-eustatic cycles (Ercilla et al., 1994; Hernández-Molina et al., 1996; Chiocci et al., 1997; Hernández-Molina et al., 2002; Lobo et al., 2004; Rabineau et al., 2005; Lobo and Ridente, 2014).

As summarized by Lobo and Ridente (2014) in their overview of high frequency depositional cycles on the modern continental margin, the major stratigraphic pattern displayed by shelf deposits is referred to the $100 \mathrm{ka}$ sea-level cycle, and consists of fairly uniform depositional sequences mostly composed by regressive facies architecture reflecting dominant control by sea level.

This stratigraphic pattern was documented early on in one of the most widely studied modern continental margins, the Gulf of Lion (South of France; Rabineau (2001, 2005), Jouet et al., (2006), Bassetti et al., (2008)). The use of an extensive dataset composed of seismic profiles, cores and numerical modeling, led to the conclusion that $100 \mathrm{ka}$ sequences of the Gulf of Lion margin were composed of repetitions of paired prisms comprised of a succession of low and high energy environments (Rabineau et al., 1998, 2005): (i) low-angle clinoforms corresponding to pro-deltaic environments at the bottom of the unit and to the distal part of the high stand system tract (HST) and (ii) high-angle clinoforms corresponding to deltaic to shoreface environments at the top of the unit and to the falling stage system tract (FSST). This pattern of internal architecture was also observed for most of pre-Last Glacial Maximum (LGM) 100 ka cycles documented on modern continental shelves and transgressive deposits. These repetitive prisms are poorly preserved and are mostly restricted to local remnant patches (Lobo and Ridente, 2014). The 100 ka depositional sequences recording Milankovitch (1930) cyclicity are regarded as $4^{\text {th }}$ order sequences of the stratigraphy hierarchical classification (Mitchum and Wagoner, 1991). The $4^{\text {th }}$ order cycles recorded from numerous shelf settings have also shown a signature of higher-frequency 20 ka Milankovitch cyclicity (5 $5^{\text {th }}$ order $s e n s u$ Mitchum and Wagoner, 1991), 
(examples: (Bassetti et al., 2008; Hernández-Molina et al., 2002; Kolla et al., 2000). These 20 ka architectural patterns are dominated by regressive progradational wedges but show relatively greater spatial and temporal variability than 100 ka sequences.

The general stratigraphic pattern of 20 and 100 ka sequences may be strongly influenced by the local tectonic setting. Thus, comparisons of the Gulf of Lion margin with the other Western Mediterranean continental margins have shown that the tectonic context locally modulates the influence of glacio-eustatic sea-level variations on the geometry and pattern of lowstand system tracts of the late Quaternary stratigraphic architecture (Chiocci et al., 1997). Nevertheless, examples of the influence of tectonics on the stratigraphic pattern of modern margins remain limited. Consequently, even though $4^{\text {th }}$ order cyclicity controls the Late Pleistocene architecture of the Mediterranean continental shelves, the influence and interplay of higher order (i.e. $<100$ ka) glacio-eustatic cycles and active tectonics need to be better documented.

The study of the northern Moroccan margin of the Nekor basin in the southern Alboran offers an opportunity to better characterize the influence of tectonics on the Middle and Upper Pleistocene stratigraphic architecture of the active margin of the Southern Alboran Sea. The tectonics of the transtensive Nekor basin has recently been characterized (Stich et al., 2005; d'Acremont et al., 2014; Lafosse et al., 2017). As the Nekor basin is transtensive, it offers an opportunity to observe how a extensive tectonics influences the architecture and the morphology of the shelf. The characterization of the morphology of the seafloor and the seismic stratigraphy in this margin makes it possible to discuss how localized subsidence affects the architecture and the physiography of the shelf.

\subsection{Tectonic and geological setting}


In contrast to the extensive seismic stratigraphic studies carried out on the northern margin of the Alboran Sea (Alonso and Maldonado, 1992; Ercilla et al., 1992, 1994, Hernández-Molina et al., 1994, 1996, 2002; Lobo et al., 2008), the Quaternary architecture of the Morocco margin in the southern Alboran Sea margin has remained poorly studied. Precursor studies (Ammar et al., 2007; Gensous et al., 1986; Tesson et al., 1987; Tesson and Gensous, 1989) revealed major longitudinal variations in the architecture of the strata of the continental shelf on both sides of the Nekor basin in relation with the local tectonic (Fig. 1) (Gensous et al., 1986).

The study area is divided into western, eastern and central sectors, each with different vertical movement controlled by active faults: (i) the western sector, the shelf west of Ras el Abib Promontory and the Ras el Abib Promontory (Figs. 2b and 4); (ii) the eastern sector, corresponding to the Ras Tarf Promontory (Figs. 2b and 5), and (iii) the central area formed by the Nekor basin and Al-Hoceima Bay (Figs. 2b and 6).

The western sector is limited by the Bousekkour fault. The eastern sector is the Ras Tarf promontory at the footwall of the Trougout fault. The central sector the bay is located offshore the Nekor basin, at the outlet of the Rhis and Nekor rivers, which drain the largest watersheds of the area (around $775 \mathrm{~km}^{2}$ and $865 \mathrm{~km}^{2}$ respectively, Fig. 1). The Nekor basin is a transtensive basin (Calvert et al., 1997; d'Acremont et al., 2014; Lafosse et al., 2017) whose activity is evidenced by earthquakes: Mw=6.0 in 1994, and Mw=6.4 in 2004 (e.g. Bezzeghoud and Buforn, 1999; Stich et al., 2005). The onshore tectonic boundaries of the Nekor basin are the NNE-SSW normal-sinistral Trougout fault eastward and the NW-SE normal Imzouren-Ajdir fault westward (Fig. 1)( Poujol et al., 2014; Van der Woerd et al., 2014). The Boudinar fault on the eastern side of the Nekor basin was active until the Quaternary and may be expressed offshore by the Ras Tarf promontory (Poujol et al., 2014; Galindo-Zaldívar et al., 2015). The Imzouren-Ajdir fault 
uplifted and offset fan-shaped terraces linked to the Rhîs River (Fig. 1)( Van der Woerd et al., 2014).

Offshore, the Nekor basin is bounded by the NE-SW en-echelon sinistral Bousekkour-Bokkoya fault zone (d'Acremont et al., 2014; Lafosse et al., 2017). In the central sector, striking NW-SE normal faults affects the sub-surface (Figs. 1 and 3). Together with the Trougout fault, these faults control subsidence (Fig. 1). On the edge of the Ras Tarf promontory, Poujol et al. (2014) observed three uplifted marine terraces at distances of $+12 \mathrm{~m},+22 \mathrm{~m}$ and $+80 \mathrm{~m}$ from the present day sea level. The lowest terrace was dated using the U/Th method and aged between $186 \mathrm{ka}$ and $203 \mathrm{ka}$ (Poujol et al. 2014) indicating an uplift rate of $0.2 \mathrm{~mm} / \mathrm{y}$. The analysis of the Bouger gravity anomaly indicates that the Nekor basin is filled with $400 \mathrm{~m}$ of Plio-Quaternary sediments, with a depocentre of the basin at the foot of the onshore Trougout fault segment (GalindoZaldívar et al., 2009).

\subsection{Oceanographic setting}

The circulation of water masses in the Alboran Sea (Atlantic water masses, AW, above 250 meters below sea-level, (mbsl) and the Western Mediterranean Deep Water WMDW, more than 300 mbsl, Ercilla et al., 2016) influences sedimentation on the continental slope and on the continental shelf in the Alboran Sea (Ercilla et al., 2016; Juan et al., 2016). The AW is characterized by an anti-cyclonic circulation that forms the West Alboran gyre (WAB, inset in Fig. 1) (Font et al., 2002; Pascual et al., 2017; Viúdez et al., 1998, 1996). The WDMW is denser and deeper than the AW (Ercilla et al. 2016). However, in the Al Hoceima area, the AW and WDMW are mixed and form the Shelf Water, (ShW) mass that circulates along the Moroccan shelf and the upper slope in a westward direction (Inset, Fig. 1) (Ercilla et al., 2016). 


\section{Material and methods}

We used swath bathymetric data and high-resolution reflection seismic profiles obtained from two oceanographic surveys performed in 2012, the Marlboro-2 and the SARAS surveys (Fig. 2a) (d'Acremont et al., 2014). The swath bathymetry was acquired using a shallow-water Reson 8101 system during the MARLBORO-2 cruise and with an EM710 system during the SARAS survey. The 2D seismic profile was acquired using a 250-500 J SPARKER source and a six-channel streamer. In addition, high-resolution parametric profiles (TOPAS PS18, $15-21 \mathrm{kHz}, 32 \mathrm{~kW}$.) were acquired during the SARAS survey. The seismic data were processed (i.e. stacked, filtered and migrated) with SEISMIC UNIX software and imported in IHS Kingdom Suite software for seismic interpretation. We processed the swath bathymetry using QUINCY and CARAIBES (IFREMER) software. The swath bathymetry from the MARLBORO-2 survey has a horizontal definition of $5 \mathrm{~m} / \mathrm{pi}$ and a vertical resolution of $0.5 \mathrm{~m}$ at depths greater than $100 \mathrm{mbsl}$. The horizontal definition of the bathymetry from the SARAS survey is $7 \mathrm{~m} / \mathrm{pi}$ and its vertical resolution is $1 \mathrm{~m}$.

This high resolution data enabled the comparaison of the physiography of the shelf with the depositional sequences (e.g. Chiocci, 1994; Martorelli et al., 2010). The physiography was interpreted from morphometric parameters (bathymetry, slope gradient, curvature) in ArcGIS. Fault segments were deciphered from linear features on the seafloor (Fig. 3) according to the maps presented in Lafosse et al., (2016). We use the term 'terrace' to describe a morphologically regular low slope gradient surface $\left(<2^{\circ}\right)$ and the term 'step' to describe an area with a relatively higher slope gradient (Figs. 4, 5 and 6). The elevations of the terraces were measured on topographic profiles according to the previous definition of a terrace. The seabed features 
described hereafter are presented on the topographic profiles and the corresponding slope gradient profile (Figs. 4b, 5b, and 6b).

The seismic data were interpreted according to the general principles of high resolution seismic and sequence stratigraphy, adequate to address analyses of Quaternary high frequency glacioeustatic signals of fourth ( 100-120 ka periodicity) and fifth orders $(\sim 40 \mathrm{ka}$ and $20 \mathrm{ka}$ periodicity), according to Tesson et al., (1990), Mitchum and Wagoner, (1991), Hunt and Tucker (1995), Posamentier et al., (1992), Plint and Nummedal, (2000); Posamentier and Morris, (2000), and Catuneanu et al., (2009, 2011). Limitations in the interpretation of the stratigraphic surfaces and units arise from the syn-tectonic deposition (Lafosse et al., 2017). As active faults produce co-seismic scarps and post-seismic wedges (e.g. Barnes and Pondard, 2010), the lateral continuity of the stratigraphic surfaces and depositional units presented in the following seismic lines is sometimes ambivalent (Figs. 8, 9, 10 and 11). Locally, they cannot be interpreted within the aforementioned stratigraphically framework.

\section{Physiography and morphological features}

\subsection{Physiographic domains}

Three physiographic domains were distinguished in the proximal continental margin of the study area based on the average slope and the water depth: (i) the continental shelf; (ii) the shelf-edge and (iii) the continental slope. The continental shelf is defined as an area with an average slope of less than $2^{\circ}$, and a water depth between $0 \mathrm{~m}$ and 95 to 125 meters below sea level (mbsl). The shelf is arbitrarily divided into the inner shelf (between 0 and $50 \mathrm{mbsl}$ ), the mid-shelf (between 50 and $95 \mathrm{mbsl}$ ), and the outer shelf (between 95 and $125 \mathrm{mbsl}$ ). The continental slope is identified as the area where the slope exceeds $2^{\circ}$ at a water depth ranging between 95 and $125 \mathrm{~m}$ (Fig. 3). The shelf edge is defined as the area of maximum curvature occurring between the 
continental slope and the outer shelf (Casalbore et al., 2017a). On the topographic profiles, this area corresponds to a variation from $2^{\circ}$ to $4^{\circ}$ at the edge of sub-marine terraces at the edge of the continental shelf (e.g. cross section A-A' and B-B4; Figs. 4).

In the western sector, the continental shelf extends further offshore than the present day shoreline, up to $\sim 5.5 \mathrm{~km}$ at the northeastern extremity of the Ras El Abid promontory (Fig. 4). In the eastern area, the width of the shelf varies between $10 \mathrm{~km}$ and $13 \mathrm{~km}$ northward (Fig. 5). The basement outcrops at the seabed along the middle shelf in the Ras Tarf and In the Ras El Abid (Fig. 5; Ammar et al., 2007; Lafosse et al., 2017). In the central sector, the shelf has an intermediate width of $\sim 7-8 \mathrm{~km}$ (Fig. 6). Eight sorts of morphological features were identified on the continental shelf and slope and are described below.

\subsection{Morphological features}

\section{Continental slope ledges}

On the upper continental slope, slope gradients reached values greater than $5^{\circ}$ locally along the Ras El Abid and Ras Tarf promontories (Figs. 4b and 5b). The slope gradient decreased to $5^{\circ}$ in the uppermost section of the slope between 150 and 130 mbsl. We defined this morphological feature as the continental slope ledge (Figs. 4 and 5). It is located $\sim 40-20 \mathrm{~m}$ below the shelf edge in the Ras el Abid and the Ras Tarf promontories (Figs. 4b and 5b).

\section{Sub-marine terraces}

From the western to the eastern sector, three successive stepped extensive surfaces of low slope gradients were identified from bathymetric data and considered as submarine terraces. Despite the segmentation of the margin, the terraces may be correlated along the shelf and are referred as ST1 to ST3 (Fig. 3). The terraces have lower slope values $\left(<1^{\circ}\right)$ in the western and eastern sector 
than in the central sector $\left(\sim 1^{\circ}\right)$, indicating more progressive deepening (in the form of a ramp) than in the eastern and the western sectors.

The three terraces ST1, ST2, and ST3 are located at depths of $c a$. 110-100 mbsl, 90-80 mbsl, and $>40 \mathrm{mbsl}$, respectively, and roughly correspond to the inner, middle and outer shelf domains (Figs. 4, 5 and 6). The ST1 terrace is narrow ( $<1 \mathrm{~km}$ wide) and can be traced from west to east in the three sectors (Fig. 3). The basinward limit of ST1 coincides with the shelf edge at 105-110 mbsl, 105-110 mbsl and 105-115 mbsl deep, in the western, central and eastern sector, respectively (Figs. 4, 5, and 6).

The basinward outer boundaries of the ST2 and ST3 terraces can be seen on bathymetry images as steps with slope values of less than $5^{\circ}$ (Figs. $4 \mathrm{~b}$ and $5 \mathrm{~b}$ ). For the ST2 boundary, the step is $5 \mathrm{~m}$ to $10 \mathrm{~m}$ high (Figs. $4 \mathrm{~b}, 5 \mathrm{~b}$, and $6 \mathrm{~b}$ ) at depths ranging from $80-85 \mathrm{mbsl}, 75-80 \mathrm{mbsl}$ and $90-95$ mbsl in the western, central and eastern sectors, respectively (Figs. 4b, 5b, and 6b). According to the bathymetry images, the ST2 terrace could be correlated in the western area and in the central sector (Fig. 3). Furthermore, the depths of ST2 differ locally. In the western sector, ST2 is affected by faults (C-C' profile, Fig. 4b; Lafosse et al., 2017). The depth of ST2 differs on each side of the Bousekkour fault, ranging from $77 \mathrm{mbsl}$ in the hanging wall to $89 \mathrm{mbsl}$ in its footwall (Fig. 4b). To the east of the eastern sector, the basinward limit of ST2 is fuzzy with no clear transition between ST2 and ST1. On the East side of the Ras Tarf, we observed a succession of breaks in the slope gradients at $\sim 150 \mathrm{mbsl}, \sim 139 \mathrm{mbsl}, \sim 105 \mathrm{mbsl}$ and $\sim 100 \mathrm{mbsl}$ (G-G' profile, Fig. 5b).

The third terrace ST3 was only identified along shelf promontories at around 25 mbsl in the western sector (Fig. 4) and at 38-40 $\mathrm{m}$ in the eastern sector (Fig. 5). The terrace extends beyond the area acquired by the multibeam bathymetry so the lateral continuity of this feature could not be established. 


\section{Slope-parallel linear features}

Linear features are visible running parallel to the outer shelf (Figs. 3, 4, and 5). They correspond to elongated features above the ST1 terrace and are hereafter referred to as 'slope parallel linear features' (SPLF). These features are located around 105 mbsl at the outer shelf in the Ras El Abid promontory (Figs. 4), and around $75 \mathrm{mbsl}$ in the Ras Tarf (Figs. 5). These linear features could correspond to erosive morphologies.

\section{Sub-aqueous dunes}

Above the promontories in the western and eastern sector (Fig. 7), two fields of undulated bedforms extend across the shelf with crests oriented perpendicular to the shelf edge. Their morphologies led us to consider them as subaqueous dunes (SD, Figs. 3, 5 and 7). In the Ras El Abid, they are 100-110 m deep, whereas in the Ras Tarf, they are shallower i.e. around 80-100 m deep. They delineate $1-3 \mathrm{~km}$ wide fields with areas of $7 \mathrm{~km}^{2}$ and $8.5 \mathrm{~km}^{2}$, respectively.

In the western sector, the vertical amplitudes of the subaqueous dunes are low $(<1 \mathrm{~m})$ and wavelengths range from $100 \mathrm{~m}$ to $500 \mathrm{~m}$. In the eastern sector, the amplitudes and wavelengths of the bedforms range between 1 to $3 \mathrm{~m}$ and 100 and $1000 \mathrm{~m}$, respectively (Fig. 7). The bedforms are asymmetrical to the higher slopes eastward (Fig. 5b). The crests of the bedforms in the Ras Tarf are rather sinuous and rounded. The sinuosity of the subaqueous dunes in the Ras Tarf promontory increases from west to east, indicating a progressive transition from $2 \mathrm{D}$ to $3 \mathrm{D}$ morphologies.

\section{Undulated bedforms and gullies in the pro-deltaic shelf}

In the central sector, $2.5 \mathrm{k} \mathrm{m}$ downstream of the outlet of the Rhis and Nekor rivers (Fig. 1), the ST1 and ST2 terraces are draped with a field of undulated bedforms, covering an area of $20 \mathrm{~km}^{2}$ (Fig. 6). The bedforms extend parallel to the slope gradient of the pro-delta wedge of the rivers; 
they have wavelengths of several hundred meters and metric amplitudes (UB; Fig. 6). They are asymmetrical, and their higher slopes dip landward (Fig. 6b). Numerous northward trending gullies affect the undulated bedforms (Figs 3 and. 6). In the proximal part of the central sector, the heads of the gullies are 40-45 mbsl. Using the topographic profiles (K-K' profile, Fig. 6b), their width and height were estimated at between $50-60 \mathrm{~m}$ and $0.5-1.5 \mathrm{~m}$, respectively. The gullies can be traced downslope and affect the whole field on undulated bedforms; however, their morphological expression progressively decreases with depth and they disappear near the shelf edge at around $105 \mathrm{mbsl}$ (Fig. 6).

\section{Crescent shaped bedforms and incisions in the continental slope of the central sector}

Crescent shaped bedforms (CSB) were revealed by bathymetry on the continental slope of the central sector between 125 and 105 mbsl (Fig. 6a and 6b). They strike parallel to the slope and extend $130 \mathrm{~m}$ to $200 \mathrm{~m}$ laterally. They consist of asymmetric undulations, with higher basinward slopes reaching up to $6^{\circ}$ (Fig. 6b). These bedforms have $60-120 \mathrm{~m}$ long wavelengths and metric amplitudes. The CSB are channeled at the heads of three incisions, linking the shelf break and the head of the incisions (I, Fig. 6a) on the continental slope. The talwegs of the incisions are affected and deviated by the active faults (Fig. 6; Lafosse et al. 2017).

\section{Late Pleistocene-Holocene stratigraphic architecture}

\subsection{Seismic units}

Five surfaces (S1 to S5), corresponding to regional scale unconformities were identified on seismic lines correlated with the study area (red lines; Figs. 8, 9, 10 and 11). These surfaces bound six distinct seismic units (u1 to u6; Figs. 8, 9, 10 and 11). These seismic units enclose several inner unconformities and variations in reflector geometries enabling the individualization 
of different types of sub-units within seismic units. These sub-units define a repetitive stratigraphic pattern that characterizes the architecture of the margin.

\section{Seismic unit boundaries}

On the continental shelf domain, the highly reflective $S$ surfaces are flat $\left(<1^{\circ}\right)$ truncate highly dipping reflectors and continue toward the basin to toplap surfaces (Figs. 8, 9, 10 and 11). In the continental upper slope of the central and eastern sector, these S surfaces are locally onlapped by reflectors of the upper seismic unit (Figs. 10 and 11). Downslope, the $\mathrm{S}$ surfaces correspond to reflector truncations defining paleo-incisions in the central sector (Fig. 10). A set of conjugated NNW-SSE normal faults encloses the paleo-incisions that record a progressive westward migration (Fig. 10).

On the continental shelf and upper slope, four types of angular unconformities can be observed within seismic units. Toward the shelf edge, local unconformities consist of $1^{\circ}-3^{\circ}$ dipping downlap surfaces at the bottom of the highly dipping parallel prograding reflectors (DS1 to DS5, dashed green lines; Figs. 8, 9, 10 and 11). These surfaces merge with the $\mathrm{S}$ surfaces, respectively, up and down the slope (Figs. 8, 9,10 and 11).

At the mid-shelf of the western and central sector, a second unconformity truncates high angle parallel reflectors (green surface in Figs. 8 and 9). This surface is flat, and is highly reflective, indicating contrasted acoustic impedance (Fig. 9). The slope of this area increases downslope from 80 mbsl and merges with S5 around 100 mbsl (Fig. 4, 8a, 8b, 8c, 8d and 9).

Locally, i.e. within the prograding seismic sub-units on the DS surfaces, a third sort of unconformity corresponds to irregular basinward dipping $\left(<10^{\circ}\right)$ downlap surfaces (dashed black lines in Figs. 8, 9 and 11) that are intercalated between high angle packages parallel to oblique reflectors. The fourth and last type corresponds to very low angle unconformities visible above 
the $\mathrm{S}$ and below the DS surfaces in the continental slope of the central and western sector (black dashed-dotted lines in Figs. 9 and 11). They are moderate to highly reflective downlap surfaces at the bottom of moderately dipping reflectors. Upslope, these unconformities merge with the $\mathrm{S}$ surfaces (Figs. 9 and 11).

The position and the morphology of ST1 on the bathymetry are comparable to the position and morphology of S5 in the seismic reflection. The result is_that S5 corresponds to ST1 (Figs. 8, 9, 10 and 11). A comparison of the positions and morphologies of ST2 and the highly reflective flat toplap at the mid-shelf (Green surface; Figs. 8 and 9) points to a similar correlation.

\subsection{Type of seismic sub-units}

\section{Distal aggrading wedges (u2a to u5a)}

On the continental slope of the central and eastern sector (Figs. 9, 10, 11 and table 1), aggrading seismic sub-units consist of a set of parallel reflectors onlapping the S surfaces (purple seismic sub-units, u2a, u3a, u4a and u5a in Figs. 9, 10 and 11). They are topped by the moderate to highly reflective downlap surfaces (Black dashed lines; Figs. 9, 10 and 11). Internal seismic facies display moderate to high amplitude parallel reflectors.

\section{Low-angle prograding wedges (u1b to u5b)}

Low-angle $\left(<1^{\circ}\right)$ prograding seismic sub-units are characterized by low to medium amplitude and low frequency reflectors showing oblique parallel prograding reflectors alternating with local sheeted reflectors (light blue seismic sub-units in Figs. 8, 9, 10, 11 and see table 1). On the continental shelf, they are visible above and below the S and DS surfaces, respectively (Fig. 9). On the slope, they downlap with very low angles on the u2a to u5a seismic sub-units (Figs. 9, 10 and 11). 
The thickness of these seismic sub-units varies depending on the local faults. $u 4 b$ reaches its maximum thickness near the Bousekkour fault in the western sector (Figs. 8a and 8b).. A change in thickness at the eastern boundary of the central sector corresponds to the delimitation of the Nekor basin by the Trougout fault (Fig. 12a). On the shelf in the central sector, the depocentre of u5a-u5b strikes NNW-SSE and is limited by the NNW-SSE normal faults.

\section{High-angle prograding shelf edge wedges (u1c to u5c)}

Five approximatively $10 \mathrm{~m}$ thick high angle prograding seismic sub-units with wedge geometries are bounded to the top and to the bottom by S1, S2, S3, S4 and S5 and the DS surfaces, respectively ( $u 1 c$ to $u 5 c)$. The u5c wedge is thicker (> $31 \mathrm{mstwt}$ ) and is deposited along the edges of the shelves of the western and eastern sector (Fig. 12b). In Ras El Abid, the position of slope parallel linear features matches the position of the toplap terminations of the u5c wedge (Figs. 4, 7e and 7f). Locally in a proximal position, several other similar high angle-prograding seismic sub-units (Fig. 7f) are developed over a flat downlap surface (blue line, Fig. 7f).

The high angle prograding shelf edge wedge is locally divided into two sub-units, $u 4 c-1, u 4 c-2$ and u5c-1 and u5c-2, respectively (Figs. 8, 9, 11 and table 1). The u4c-1 and u5c-1 sub-units consist of maximum 25 mstwt thick packages of reflectors. They exhibit high angle $\left(<10^{\circ}\right)$ medium amplitude and high frequency reflectors (Table 1). The u4c-2 and u5c-2 sub-units are characterized by medium amplitude, medium frequency reflectors with relatively lower_angles $\left(1^{\circ}-2^{\circ}\right)$ (table 1). u5c-1 pinches out seaward between $125 \mathrm{mbsl}$ and $140 \mathrm{mbsl}$. These depths correspond to the depth of the ledges observed on the present day seafloor (Fig 4 and 5).

In the western part of the central sector of the shelf, the u5c-1 and u4c-1 seismic sub-units are located $5 \mathrm{~km}$ landward from u5c-2 and u4c-2 (Fig. 9). In contrast, in the western and eastern sectors, u5c-1 and u5c-2 are physically attached (Fig. 10). In the eastern sector, the u5c-2 seismic 
sub-unit exhibits a downward shift to a depth of $140 \mathrm{mbsl}$ (Fig. 11b). In the mid-shelf of the central sector, estimates of maximum thickness of u5c-I ranged from 10 to 24 mstwt (dashed line (1); Fig. 12b). At the shelf edge, the thickness of u5c-II was estimated to range from 24 to19 mstwt (dashed line (2) on Fig. 12b).

\section{Distal hummocky wedges (u3d to u5d)}

In the upper continental slope in the central sector, seismic units of moderate reflectivity hummocky to wavy sub-parallel reflectors (u3d, u4d, and u5d; Fig. 9 and table 1) are capped by the S3 and S5 unconformities (Fig. 9). Their spatial distribution (Figs. and 10) shows that they correspond to sediment deposited around the paleo-incisions. The lateral extent of these seismic sub-units is difficult to decipher due to the faults. Their extensions restricted to the distal central basin suggest that they could have a lobate geometry.

\section{High angle prograding mid-shelf wedges (u6b)}

On the present day middle shelf in the western and central sector (Figs. 8 and 9), a $10 \mathrm{~m}$ thick oblique prograding seismic unit (u6c) with a wedge geometry is also visible (table 1). Relatively steep internal reflectors $\left(<5^{\circ}\right)$ show low to medium amplitude, similar to the seismic facies of the previously described high angle prograding seismic units. The u6c wedge is stratigraphically above and younger than S5 (Figs. 8a to 8d, 9a, and 9b). Its mid-shelf location reveals a backstepping evolution of deposition following the previous prograding high angle wedges at the shelf edge (Figs. 7 and 9).

\section{Wavy mid-shelf wedges (u6c)}

Several wavy mid-shelf wedges were identified in the central part of the Nekor bay in the central sector. They consist of a $5 \mathrm{~m}$ to $10 \mathrm{~m}$ thick seismic sub-unit of wavy sub-parallel reflectors. They pinch out seaward around 100 mbsl (u6c; table 1 and fig. 9). The undulated bedforms are 
stratigraphically at the top of the upper seismic unit and are thus younger than the middle shelfedge wedge and younger than the ST2 terraces (Fig. 9). This seismic sub-unit corresponds to the undulated bedforms visible at the seafloor and is not recognizable at depth.

\section{Inner shelf wedges}

The inner shelf wedges show poor lateral continuity and lobate geometry (Figs. $8 \mathrm{~g}$ and $8 \mathrm{~h}$ ). They directly overlie the irregular acoustic basement and consist of prograding low amplitude reflectors with downlap terminations on an erosive surface. Their lobate shapes are asymmetric along the WE axis with steeper forsets toward the west (Figs. $8 \mathrm{~g}$ and $8 \mathrm{~h}$ ). Their top flat surface lies around 30-20 mbsl and corresponds to ST3 (Fig. 4). A faint angular unconformity is visible on top of an oblique parallel reflector (dashed dotted green line, Fig. 8g) that divides the inner shelf wedge into two package reflectors with westward prograding reflectors to the base and a more aggrading geometry to the top. Laterally, this surface corresponds to a flat $\left(<1^{\circ}\right)$ top of the acoustic basement (Figs. $7 \mathrm{~g}$ and $7 \mathrm{~h})$.

\section{Interpretation and discussion}

\subsection{Chronostratigraphy of regional seismic unconformities}

We interpret the five regional unconformities (S1 to S5) identified along the margin as composite erosional surfaces. Similar erosional surfaces associated with seismic units have already been observed around the Mediterranean for the Middle Upper Pleistocene interval (Chiocci et al., 1997; Chiocci, 2000; Ridente et al., 2012; Lobo et al., 2004; Rabineau et al., 2005; Lobo and Ridente, 2014). For example, in the Gulf of Lion and on the Roussillon shelf, similar regional uniformities at the top of the high angle prograding shelf edge wedges were dated to the maximum regressions and early transgression in $4^{\text {th }}$ order relative sea level cycles (Lobo et al., 
2004; Rabineau, 2001; Rabineau et al., 2005). Based on a sequential stratigraphic approach, these erosive unconformities correspond to maximum regressive surfaces below the shelf edge and are considered by some authors as sequence boundaries (Catuneanu et al., 2011; Zecchin and Catuneanu, 2013). In comparison with the other Mediterranean margins, it thus seems reasonable to attribute the S1 to S5 surfaces to the major sea drops in level related to the 100 ka cycles that have been occurring since the Middle Pleistocene

Within the $4^{\text {th }}$ order depositional sequences, inner unconformities linked to high angle prograding wedges correspond to basal surfaces of regression (Figs. 8, 9 and 10) but could also reflect a change in accommodations linked to $5^{\text {th }}$ order cyclicity (20 ka period) (Lea et al., 2002; Lisiecki and Raymo, 2005; Waelbroeck et al., 2002) as another example of a signature of higherfrequency Milankovitch cyclicity. Nevertheless, as discussed below (section 5.4) interpretations of stratigraphic surfaces and seismic sub-units might be biased by the local tectonic. Yet, at the seafloor, the young ages of the wedge and seabed features reduce the possibility of misinterpretation.

\subsection{Sequential interpretation of seismic sub-units.}

\section{Highstand system tract (HST)}

The HSTs are relatively small volumes of sediments in the sedimentary record of the Late Pleistocene, because they were laid down during a relatively short period of time and were erased during the subsequent sea level fall (Ercilla et al., 1994; Lobo and Ridente, 2014). However, the undulated bedforms and associated seismic sub-units provide clues concerning sedimentation during the highstand period.

The Holocene deltaic sedimentation in the Al Hoceima bay is recognizable on the seafloor as UB (Fig. 6). These bedforms corresponds to the thickening landward sub-unit u6c (Fig. 9). The 
longitudinal extent of the bedforms in front of the modern river outlets in the Al Hoceima Bay denotes the kilometer wide fluvial influence and the high sedimentary fluxes during the Holocene (Fig. 3). Comparable bedforms and seismic sub-units have been recorded in front of river outlets on the shelfs around the Mediterranean Sea (Casalbore et al., 2017b; Lobo et al., 2014; Ridente and Trincardi, 2002; Urgeles et al., 2011) using the term pro-deltaic undulations. These bedforms are assumed to have developed in Holocene pro-deltaic mud in response to high sedimentary fluxes and hyperpycnal flows (Casalbore et al., 2011, 2017b; Cattaneo et al., 2004; Lobo et al., 2014; Mulder et al., 2003; Urgeles et al., 2011).

At a more distal position, the trails of crescent shaped bedforms linking the present day marine incisions and the foot of the ST1 terrace (Figs. 3 and 6) suggest that channelized erosion or deposition occurred at the head of the marine incision during the Holocene highstand. The estimated sizes of these structures are in the range of small scale sediment waves with mixed relief in a confined setting (Symons et al., 2016). The origin of these features is not clear but they could be the result of internal tides, seafloor deformation and/or supercritical flows (e.g. Cartigny et al., 2014; Paull et al., 2011; Symons et al., 2016). As suggested by Symons et al., (2016), the active tectonics and the channelized organization of the CSB could be the result of seafloor destabilization and breaching, interacting with channeled flows to form these small scale features. The reworking of older depositional units on the continental slope shows that in an active basin like the Nekor, the incisions are active, pointing some transfers of sediments from the shelf to the upper slope during sea-level highstand.

Elsewhere, the highstand deposits are represented by an inner shelf wedge topped by the ST3 terrace (Figs. 3, 8g and 8h). The edge of ST3 is located around $25 \mathrm{mbsl}$, and in its size and position on the shelf, the terrace closely resembles those previously described on the northern Alboran and in the Tyrrhenian margins by Hernández-Molina et al., (2000), and references 
therein, and by Casalbore et al., (2017b) as an infralittoral prograding wedge (IPW) and near shore submerged depositional terraces. The last two authors interpreted the wedges as the result of downwelling storm currents and sediment transport from the surf zone and shoreface during stormy conditions.

At more distal positions in the eastern and western shelf sectors, modern HST might be represented by thin packages of draping reflectors extending across the mid-shelf. However, the ringing at the seafloor and the vertical resolution linked to the seismic acquisition often ignores the observation of such seismic sub-units for the most recent deposits. As demonstrated for transgressive sediments and highstand sediments in the Gulf of Lion (e.g. Bassetti et al., 2008), it is possible that in the central sector (Figs. 11 and 12a), very fined grained sediments could be transferred below the shelf edge. In that case, the tops of the distal aggrading wedges would correspond to the HST deposits (Fig. 10).

\section{Falling stage system tract (FSST) to lowstand system tract (LST)}

At the mid-shelf in the subsiding central sector (Fig. 9), the succession of prograding low angle ( $u 1 b$ to $u 5 b)$ and high angle ( $u 1 c$ to $u 5 c$ ) wedges could be a local equivalent to the succession of PI and PII prisms described in the Gulf of Lion by Rabineau et al., (2005). Although the topsets and the forsets of the prograding low angle wedge do not appear to be preserved, the u1b to u1c seismic sub-units can be interpreted as preserved regressive prisms, denoting a basinward migration of the shoreline. Based on the similarity of facies and position on the shelf to those described in the Gulf od Lion (Lobo and Ridente, 2014 and references therein; Rabineau, 2001; Rabineau et al., 2005), these sub-units correspond to regressive deposits belonging to the FSST (sensu Catuneanu et al., 2011). Conversely, in the central sector (Fig. 9), u6c is widely distributed on the shelf. Therefore, it is likely that basal reflections of low-angle prograding sub-units should 
be interpreted as remnants of the regressive highstand periods preserved by the transtensive tectonics of the Nekor basin (Figs. 9 and 10).

On the shelf edge, u1c to u5c can be interpreted as regressive deposits during the falling stage and correspond to a lowstand system tract (sensu Catuneanu et al., 2011). Below the high angleprograding wedge, the DS surfaces correspond to the regressive surface of marine erosion and the regressive surface of a marine erosion updip (Zecchin and Catuneanu, 2013). The toplap surface corresponds to a sub-aerial erosive surface in response to the base-level fall associated with the seaward migration of the shoreline (Figs. 8, 9 and 11). Located on the upper continental slope, u3d, u4d, and u5d (Fig. 9) can be correlated with the prograding high angle wedge updip. They are similar in facies and stratigraphic position to the lowstand deposits described in the Gulf of Lion for 24 ka old sediments in an coarsening-up sequence (Jouet et al., 2006) or at the bottom of forced regressive wedge in the Adriatic (Ridente and Trincardi, 2002). High angle prograding wedges deposited at the shelf edge can be locally confused with early transgressive deposits (healing phase) as demonstrated in the Gulf of Lion (Bassetti et al., 2008). Yet, these earlytransgressive sub-units are difficult to distinguish from LST at the scale of seismic reflexion, as reported in Bassetti et al., (2008).

\section{Internal architecture of high angle prograding wedges}

In the western sector (Fig. 7), u5c-1 and u5c-2 are attached but capped by the ST1 surface that reworked both seismic sub-units. Their internal architectures differ from west to east (Figs. 8b, and $8 \mathrm{~d}$ ). We consider these differences in geometry to be the consequence of different vertical motions linked to the Bousekkour fault (Fig. 7b). In the eastern sector (Fig. 11), u5c-1 and u5c-2 are distinct in the west flank (Figs. 11b and 11b) but not in the east flank of the Ras Tarf promontory (Figs. 11c and 11d). Here again, the difference in internal architecture may be the 
result of different vertical motions linked to the Trougout fault. We interpret u5c-1 and u5c-2 as different regressive $\left(5^{\text {th }}\right.$ order) sequences that might be linked to the step wise variation of the base sea-level variation within the $100 \mathrm{ka}$ cycle as demonstrated from seismic reflexion and borehole investigations in the Gulf of Lion (Bassetti et al., 2008; Jouet et al., 2006).

In the central sector (Fig. 9), u4c-1 and u4c-2; u5c-1 and u5c-2 are physically detached, are prograding over the low-angle prograding seismic sub-units, and are capped by the same flat high amplitude unconformities (Fig. 9). The decrease in the distance between the wedges (Fig. 12a) indicates that the distinction is a local effect restricted to the west part of the Al-Hoceima Bay and suggests an equivalent stratigraphic position.

It is not clear if the wedges were originally separated or belong to the same $4^{\text {th }}$ order regressive sequence. One hypothesis is that the local tectonic subsidence and physiography play roles in this configuration, as proposed for gently dipping shelf in Posamentier and Morris, (2000). The geometry would allow a fast advance of the shore line. As a result, the FSST in the mid-shelf (mid-shelf detached regressive deposit, MSDRD, Fig. 14b) would be preserved and detached above younger preserved regressive deposits at the shelf edge (shelf-edge detached regressive deposits SEDRD, Fig. 14b). The absence of regressive sub-units between u4c-1 and u4c-2; u5c-1 and u5c-2 seismic sub-units might be enhanced by subaerial exposures and subsequent wave ravinement.

A second hypothesis is that the $\mathrm{u} 4 \mathrm{c}-1$ and $\mathrm{u} 5 \mathrm{c}-1$ sub-units are younger than $\mathrm{u} 4 \mathrm{c}-2$ and $\mathrm{u} 5 \mathrm{c}-2$, respectively. This would imply that $\mathrm{u} 5 \mathrm{c}-1$ and $\mathrm{u} 6 \mathrm{~b}$ belong to the same depositional sequence and are stacked and preserved in the mid-shelf. It would contradict the general model for regressive system tracts in a low gradient configuration, modulo higher sedimentary fluxes (Posamentier and Morris, 2000), in which the physiography promotes fast progradation of the regressive deposits. From the configuration of the shelf, we thus favor the first hypothesis. 


\section{Transgressive system tract (TST)}

As defined above, TSTs correspond to sediments above the marine regressive surface (MRS) landward and above the wave-ravinement surface reworking the MRS at the outer-shelf (e.g. Zecchin and Catuneanu, 2013). At the start of the sea level rise, the wave-ravinement led to the reworking of older deposits at the shelf wedge associated with the seaward motion of the shoreline (the 'healing phase' in Posamentier and Allen, 1993). In a similar way, slowstand or stillstand during the younger stage of the transgression could contribute to the formation of a marine terrace at more proximal positions (Zecchin et al., 2011). The preservation and observation of transgressive deposits at a seismic scale depend on the physiography of the shelf and on the accumulation rates delivered during the Late Quaternary transgressive periods (Ercilla et al., 1994; Cattaneo and Steel, 2003). The products of the wave ravinement during the earlyTST were likely deposited distally below the storm wave level (e.g. Jouet et al., 2006; Lobo et al., 2004).

\section{Early transgressive system tract (TST)}

It follows that the early-TST corresponds to the distal aggrading seismic developed below the shelf edge and progressively onlapping the high-angle prograding wedge (u1a to u6a; Figs. 7, 8, 9, 10 and 11). These seismic sub-units mark the turnaround between progradational and retrogradational stacking patterns. Their geometry indicates progressive marine infilling and increasing accommodation. Depending on the depth of the base level, the early-TST deposits correspond to u1a to u6a, progressively infilling the space on the high angle prograding-wedge. They might be preserved locally, like between the two segments of the Bousekkour fault (Fig. $7 b$ ), where a local increase in subsidence could contribute to the preservation of the TST.

\section{Middle to late-TST}


This seismic sub-unit (u6b) is outbuilding and up-building; the geometry of internal reflectors and the concave-up shoreline trajectories (green arrow; Fig. 7b) indicate that the rate of aggradation increased with time (Catuneanu et al., 2011). The flat surface ST2 corresponds to the top of u6c with which it appears to be genetically related (Figs. 7 and 8); ST2 continues from the flat top of $\mathrm{u} 6 \mathrm{~b}$ to the top of acoustic basement landward, and suggests that this surface is a single wave-cut platform landward, a depositional terrace (sensu Casalbore et al., 2017a) seaward, and that $\mathrm{u} 6 \mathrm{~b}$ corresponds to the sediments deposited below this surface of the ravinement. Similar terraces and mid-shelf high angle prograding wedges have been described in the Ionian-Calabrian (Zecchin et al., 2015a, 2011), in the Tyrrhenian margins (Casalbore et al., 2017a, 2018; Chiocci and Orlando, 1996; Pepe et al., 2014) or in Alboran (Martinez-Martos et al., 2016) and attributed to the post-LGM transgression. It follows that $\mathrm{u} 6 \mathrm{~b}$ corresponds to a preserved TST at the midshelf.

The transgressive sequence is likely to be incompletely recorded in our observation. Younger TST deposits must be deposited in a more proximal position, at the bottom of the inner-shelf wedges (Figs. 7hg and 7h), as suggested in other context (Martínez-Carreño et al., 2017), or form a back-stepping barrier-island and shoreface in the poorly imaged central sector of the study area, as demonstrated in the Ebro delta (Miller et al., 2013).

\subsection{Formation and age of the submarines terraces}

The submarine terraces observed in the continental shelf of the Moroccan margin are comparable with features in the Mediterranean area (e.g. Casalbore et al., 2017a; Martinez-Martos et al., 2016; Zecchin et al., 2011). Hernández-Molina et al., (2000) and Casalbore et al., (2017a) propose that the sedimentary processes involved in the formation of the nearshore Infralittoral Prograding wedges (IPW), may also be considered in the formation of LST or early-TST. They 
would correspond to deposition below storm-wave level during lowstand and stillstands occurring during Last Glacial Maximum (LGM) and early stages post-LGM. In the same way, the submarine terraces developed at the top of the IPW by wave ravinement during a period of low rates of variation of eustatic sea-level (Anderson et al., 1999, Zecchin et al., 2011). Considering a relative seal-level curve with respect to the morphology of the shelf of the northern margin of the Alboran sea (Martinez-Martos et al., 2016), the ledges on the continental slope (Figs. 3, 4 and 13) could thus correspond to the limit of the action of storm waves limit during the Last Glacial Maximum lowstand (Casalbore et al., 2017b; Jouet et al., 2006). Based on the relative sea level at Gibraltar (Grant et al., 2014), we assume that the maximum regression would correspond to a $-110 \mathrm{~m}$ fall during the LGM and therefore that ST1 was built during the Last Glacial Maximum from $30 \mathrm{ka}$ to $18 \mathrm{ka}$ (Fig. 13). In this way, reworked sediments would correspond to the early TST prograding wedge u6a at the shelf edge.

Following Casalbore et al., (2017a), deposition of high angle prograding wedges at the mid-shelf (u6b) and the associated ST2 terrace followed similar processes to IPW deposition. Slowdowns in the sea-level rise enhanced wave-ravinement and the accumulation of regressive deposits on top of the previous marine terrace (Anderson et al., 1999; Zecchin et al., 2011). All those processes may have coincided during the transgression, post-LGM and would have been induced by shorter lived sea-level stillstand. Referring the $c a .80$ mbsl bathymetry of ST2, its formation suggests an age of around $-15 \mathrm{ka}$, in relation with the stillstand occurring during Old Dryas period prior the MWP1-A (Fig. 13)(Lambeck et al., 2014). Nevertheless, it requires that processes leading the deposition and preservation of high angle prograding shelf at the mid-shelf are more effective during the short-lived TST stillstand than during the HST. In a moderately starved shelf (Fig. 14c), the good preservation and the thickness of TST are likely to be enhanced by the active tectonic and lateral transports. In a highly supplied gently dipping shelf (Fig. 14c), 
regressive deposits at the mid-shelf corresponds to deposition of deltaic and shoreface deposits from the mid-transgression. Both evolutions can be considered in this study relative to the segment of the shelf: in Al Hoceima Bay, the sedimentary supply is high in contrast with the relative starved open shelves flanking the bay. By correlating a relative seal-level curve with the morphology of the shelf at the northern margin of the Alboran sea, Martinez-Martos et al., (2016) propose that one $110 \mathrm{mbsl}$ and one $80 \mathrm{mbsl}$ deep terrace correspond to marine-cut terraces at -20 ka and from a slowstand at around $-12 \mathrm{ka}$, respectively. The ca. 80 mbsl bathymetry of ST2 suggests an age around -15 ka linked to the stillstand occurring prior the MWP1-A (Fig. 13).

\subsection{Tectonic and physiographic control on the stratigraphic geometry}

\section{Regional tectonics vs global sea-level}

Active faults bound the Nekor basin graben, accommodate the rapid extension in the central sector and largely control the geomorphology and the sedimentary architecture identified across the Morocco margin. The growth pattern changes from west to east in relation with the local tectonics. In the western sector, in the hanging wall of the Bousekkour fault, the shelf is aggrading (Fig. 8). In the central sector, the position of prograding high angle seismic units indicate the back steeping of the shelf (Fig. 9), whereas in the eastern sector, toward the hanging wall of the Trougout fault, the shelf is clearly prograding (Fig. 11a and b). This shows that the accommodation rates differ in each sector. The segmentation of the Morocco margin by the active faults leads to variations in vertical movements and sedimentary fluxes along the margin and results in lateral variation in potential preservation of the system tracts. These differences in preservation ultimately controlled the architecture of the margin in the Al-Hoceima area after the correlation of the sub-marine terraces in the Late Pleistocene. 
The rates of glacial-interglacial sea level variations in the Quaternary are usually considered higher than rates of vertical tectonic motions and as a consequence, as the main parameter controlling accommodation through continental shelves. Since $125 \mathrm{ka}$, recent calibration of the relative sea level curve indicates peaks in rates of sea level variation reaching more than $20 \mathrm{~mm} / \mathrm{y}$ every $20 \mathrm{ka}$ (sea level rise), greater than $46 \mathrm{~mm} / \mathrm{y}$ during the MWP1-A (Deschamps et al., 2012) and more than 10 times lower values during sea level fall (Grant et al., 2012; Lambeck et al., 2014). These values are higher than $0.1 \mathrm{~mm} / \mathrm{y}$ which is the rates of vertical motion in the study area for the same period (Poujol et al., 2014). Nevertheless, this rate of vertical motion is a mean that was measured from the elevation of highstand terraces onshore in the footwall of the normal Trougout fault (Fig. 1), it does not represent potential short term increases in the rate of vertical displacement occurring during renewed growth periods along active fault segments (e.g. Barnes and Pondard, 2010). Therefore, the rates of tectonic subsidence could be much higher during short periods and closer to the rate of sea level variations, leading to rapid changes in accommodation rates. It follows that the stratigraphic geometry of the Nekor margin basin is strongly influenced by tectonics and that local unconformities and geometries of seismic subunits linked to $5^{\text {th }}$ order cycles could also result from renewed periods of growing tectonic activity.

\section{Evolution of stratigraphic geometry along the margin}

The potential of preservation of the system tracts and stratigraphic geometries observed along the margin are the result of the combination of global sea level variation, tectonic subsidence, sedimentary fluxes physiography and hydrodynamics as illustrated in figure 14. Active faults bound the Nekor basin graben and accommodate the rapid extension in the central sector and largely control the geomorphology and the sedimentary architecture across the Morocco margin. The growth pattern changes from west to east in relation with local tectonics. In the western 
sector, in the hanging wall of the Bousekkour fault, the shelf is aggrading (Fig. 8). In the central sector, the position prograding high angle seismic units indicate the back stepping of the shelf (Fig. 9), whereas in the eastern sector, toward the hanging wall of the Trougout fault, the shelf is clearly prograding (Fig. 11). This indicates that the accommodation rates differ in each sector. In the western sector (Figs. 3 and 8), the shelf is probably moderately starved as no large rivers feed it (Fig. 1). This resulted in a stair case morphology with successive well defined flat terraces corresponding to erosive wave cut surfaces or to depositional terraces on top of regressive deposits. The regressive deposits deposited during $4^{\text {th }}$ order falling stages are preserved toward the shelf edge (Fig. 14a). However, thick syn-tectonic deposits may be locally preserved in local tectonic lows (Fig. 3 and 8).

This contrasts with the gently dipping morphology in the central sector linked to the higher sedimentary fluxes and tectonic subsidence (Figs. 1, 3, 9 and 10). This physiography enabled the preservation of detached regressive wedges deposited during the $4^{\text {th }}$ order fall in sea level (Figs. 3, 9 and 14b). Crescent shaped bedforms are evidence that erosion or deposition occurred in the talwegs of the incisions on the upper continental slope. The reworking of older depositional units on the continental slope indicates that in an active basin like the Nekor basin, the incisions are active not only during the lowstand but also during the following transgression and highstand, implying continuous transfers and remobilization of sediments from the shelf to the upper slope during sea level transgression and highstand.

The wide flat promontory in the eastern sector differs from the western and central sectors with its clear progradational trend and the absence of a well-defined terrace on top of the regressive wedge at the mid-shelf (Fig. 11). From west to east in the eastern sector (Fig. 11), the different stacking patterns suggest a longitudinal variation in accommodation, probably linked to a tectonic tilt of the footwall eastward (Figs. 3 and 11). The progradation of the shelf is likely a 
consequence of the uplift of the Ras-Tarf (Ammar et al., 2007; Poujol et al., 2014): the different geometry from that in the other sectors is linked to its position on the uplifted footwall of the Trougout fault resulting in long term lower rates of accommodation. The absence of preserved wedges of post-LGM deposits can be explained by the flat paleo-topography of the promontory (Fig. 14d). This morphology may have helped limit accumulation rates during the post-LGM transgression (Cattaneo and Steel, 2003), restricted to thin transgressive deposits masked by ringing or below the vertical resolution of the seismic reflection (Fig. 14d).

These results show that stacking pattern of seismic units and sub-units at the margin of the Nekor basin exhibits readily discernible trends according to the segmentation of the continental shelf. While the 100 ka sequences are clearly linked to glacial/interglacial Milankovitch cyclicity, the stratigraphic signature of the inner seismic sub-units records strong control by active tectonics and differs locally from the classical model of $4 \mathrm{th}^{\text {th }}$ order sequence. Local variations in the thickness of seismic sub-units could record local co-seismic increases in accommodation related to $4^{\text {th }}$ order sequence. Fine tuning the age of the stratigraphic surfaces with absolute dating should provide exceptional insight into the co-seismic sedimentary processes that occur in active basins.

\section{Conclusions}

In the study area (Nekor basin, Morocco), eustatic control of shelf deposits in the Late Pleistocene does not differ from that of other Mediterranean shelves. However, the localized variation in vertical motion appears to influence the physiography and the preservation of the system tracts. On the continental shelf and slope, $4^{\text {th }}$ order variation in relative sea level controls the stratigraphy of the shelf. Tectonic segmentation appears to exert a strong influence on the physiography of the regional unconformities and on the geometry of the seismic sub-units. 
High resolution multibeam bathymetry revealed that the staircase morphology of the shelf is linked to still/slowstand of eustatic variation from the LGM lowstand to the Holocene highstand. In the western and eastern sector, HST and TST are poorly preserved above the shelf edge. The HST corresponds to the IPW nearshore. FSST and LST are stacked and preserved at the shelf edge. In the central sector, higher sedimentary fluxes and the Late Pleistocene subsidence of the Nekor basin enabled the preservation of low angle regressive deposits that can account for HST or early-FSST. On top of those wedges, detached high angle prograding wedges are interpreted as preserved FSST and LST. The submarine terraces and the associated deposits reflect the processes governing the physiography. We propose those mid-shelf terraces are a product of wave ravinement rather than of shoreface remobilization and deposition below the limits of the action of storm-waves.

However, the lack of absolute dating and local tectonics limit our interpretation. Planned sampling in the area (Albacore, 2019, PI: Dr. Elia d'Acremont, Dr. Lafuerza) with up to $40 \mathrm{~m}$ cores will help decipher what controls the local stratigraphy. The Al-Hoceima area offers a rare opportunity to study the interactions between active tectonics and Pleistocene sea level change in a shelf setting that will certainly advance our understanding of paleo-seismology and very high order stratigraphy.

\section{$\underline{\text { Acknowledgments }}$}

We thank the members of the SARAS and Marlboro cruises in 2011 and 2012. This work was funded by the French program Actions Marges, the EUROFLEETS program (FP7/2007-2013; $\mathrm{n}^{\circ} 228344$ ), project FICTS-2011-03-01. Seismic reflection data were processed using the Seismic UNIX SU and Geovecteur software. The processed seismic data were interpreted using Kingdom IHS Suite@software. This work also benefited from a State Grant from the French Agence 
Nationale de la Recherche (ANR) in the Program «Investissements d'avenir » reference ANR10-LABX-19-01, Labex Mer and from the Fauces Project (Ref CTM2015-65461-C2-R; MINCIU/FEDER) financed by "Ministerio de Economía y Competitividad y al Fondo Europeo de Desarrollo Regional" (FEDER). We are grateful to Romain Cancoët, Christophe Prunier (UMR6538) for their help with bathymetry and seismic acquisition. 


\section{Bibliography}

Alonso, B., Maldonado, A., 1992. Plio-Quaternary margin growth patterns in a complex tectonic setting: northeastern Alboran Sea. Geo-Mar. Lett. 12, 137-143. https://doi.org/10.1007/BF02084924

Ammar, A., Mauffret, A., Gorini, C., Jabour, H., 2007. The tectonic structure of the Alboran Margin of Morocco. Rev. Soc. Geológica Esp. 20, 247-271.

Anderson, R.S., Densmore, A.L., Ellis, M.A., 1999. The generation and degradation of marine terraces. Basin Res. 11, 7-19. https://doi.org/10.1046/j.1365-2117.1999.00085.x

Barnes, P.M., Pondard, N., 2010. Derivation of direct on-fault submarine paleoearthquake records from high-resolution seismic reflection profiles: Wairau Fault, New Zealand: SUBMARINE PALEOEARTHQUAKE RECORDS. Geochem. Geophys. Geosystems 11, n/a-n/a. https://doi.org/10.1029/2010GC003254

Bassetti, M.A., Berné, S., Jouet, G., Taviani, M., Dennielou, B., Flores, J.-A., Gaillot, A., Gelfort, R., Lafuerza, S., Sultan, N., 2008. The 100-ka and rapid sea level changes recorded by prograding shelf sand bodies in the Gulf of Lions (western Mediterranean Sea): RAPID CYCLICITY IN SHOREFACE DEPOSITS (GULF OF LIONS). Geochem. Geophys. Geosystems 9, n/a-n/a. https://doi.org/10.1029/2007GC001854

Bezzeghoud, M., Buforn, E., 1999. Source parameters of the 1992 Melilla (Spain, MW= 4.8), 1994 Alhoceima (Morocco, MW= 5.8), and 1994 Mascara (Algeria, MW= 5.7) earthquakes and seismotectonic implications. Bull. Seismol. Soc. Am. 89, 359-372.

Calvert, A., Gomez, F., Seber, D., Barazangi, M., Jabour, N., Ibenbrahim, A., Demnati, A., 1997. An integrated geophysical investigation of recent seismicity in the Al-Hoceima region of North Morocco. Bull. Seismol. Soc. Am. 87, 637-651.

Cartigny, M.J.B., Ventra, D., Postma, G., van Den Berg, J.H., 2014. Morphodynamics and sedimentary structures of bedforms under supercritical-flow conditions: New insights from flume experiments. Sedimentology 61, 712-748. https://doi.org/10.1111/sed.12076

Casalbore, D., Falese, F., Martorelli, E., Romagnoli, C., Chiocci, F.L., 2017a. Submarine depositional terraces in the Tyrrhenian Sea as a proxy for paleo-sea level reconstruction: Problems and perspective. Quat. Int., Quaternary coastal and marine studies in Central Mediterranean 439, 169-180. https://doi.org/10.1016/j.quaint.2016.02.027

Casalbore, D., Ridente, D., Bosman, A., Chiocci, F.L., 2017b. Depositional and erosional bedforms in Late Pleistocene-Holocene pro-delta deposits of the Gulf of Patti (southern Tyrrhenian margin, Italy). Mar. Geol. 385, 216-227. https://doi.org/10.1016/j.margeo.2017.01.007

Casalbore, D., Romagnoli, C., Adami, C., Bosman, A., Falese, F., Ricchi, A., Chiocci, F.L., 2018. Submarine Depositional Terraces at Salina Island (Southern Tyrrhenian Sea) and Implications on the Late-Quaternary Evolution of the Insular Shelf. Geosciences 8, 20. https://doi.org/10.3390/geosciences8010020

Casalbore, D., Romagnoli, C., Bosman, A., Chiocci, F.L., 2011. Potential tsunamigenic landslides at Stromboli Volcano (Italy): Insight from marine DEM analysis. Geomorphology 126, 42-50. https://doi.org/10.1016/j.geomorph.2010.10.026

Cattaneo, A., Correggiari, A., Marsset, T., Thomas, Y., Marsset, B., Trincardi, F., 2004. Seafloor undulation pattern on the Adriatic shelf and comparison to deep-water sediment waves. Mar. Geol. 213, 121-148. https://doi.org/10.1016/j.margeo.2004.10.004 
Cattaneo, A., Steel, R.J., 2003. Transgressive deposits: a review of their variability. Earth-Sci. Rev. 62, 187-228. https://doi.org/10.1016/S0012-8252(02)00134-4

Catuneanu, O., Abreu, V., Bhattacharya, J.P., Blum, M.D., Dalrymple, R.W., Eriksson, P.G., Fielding, C.R., Fisher, W.L., Galloway, W.E., Gibling, M.R., Giles, K.A., Holbrook, J.M., Jordan, R., Kendall, C.G.S.C., Macurda, B., Martinsen, O.J., Miall, A.D., Neal, J.E., Nummedal, D., Pomar, L., Posamentier, H.W., Pratt, B.R., Sarg, J.F., Shanley, K.W., Steel, R.J., Strasser, A., Tucker, M.E., Winker, C., 2009. Towards the standardization of $\begin{array}{lllll}\text { sequence } & \text { stratigraphy. } & \text { Earth-Sci. } & \text { Rev. }\end{array}$ https://doi.org/10.1016/j.earscirev.2008.10.003

Catuneanu, O., Galloway, W.E., Kendall, C.G.S.C., Miall, A.D., Posamentier, H.W., Strasser, A., Tucker, M.E., 2011. Sequence Stratigraphy: Methodology and Nomenclature. Newsl. Stratigr. 44, 173-245. https://doi.org/10.1127/0078-0421/2011/0011

Chiocci, F.L., 2000. Depositional response to Quaternary fourth-order sea-level fluctuations on the Latium margin (Tyrrhenian Sea, Italy). Geol. Soc. Lond. Spec. Publ. 172, 271-289. https://doi.org/10.1144/GSL.SP.2000.172.01.13

Chiocci, F.L., 1994. Very High-Resolution Seismics as a Tool for Sequence Stratigraphy Applied to Outcrop Scale--Examples from Eastern Tyrrhenian Margin Holocene/Pleistocene Deposits. AAPG Bull. 78, 378-395.

Chiocci, F.L., Chivas, A.R., 2014. Continental Shelves of the World: Their Evolution During the Last Glacio-Eustatic Cycle. Geological Society of London.

Chiocci, F.L., Ercilla, G., Torre, J., 1997. Stratal architecture of Western Mediterranean Margins as the result of the stacking of Quaternary lowstand deposits below 'glacio-eustatic fluctuation base-level.' Sediment. Geol. 112, 195-217. https://doi.org/10.1016/S00370738(97)00035-3.

Chiocci, F.L., Orlando, L., 1996. Lowstand terraces on Tyrrhenian Sea steep continental slopes. Mar. Geol. 134, 127-143. https://doi.org/10.1016/0025-3227(96)00023-0

d'Acremont, E., Gutscher, M.-A., Rabaute, A., Mercier de Lépinay, B., Lafosse, M., Poort, J., Ammar, A., Tahayt, A., Le Roy, P., Smit, J., Do Couto, D., Cancouët, R., Prunier, C., Ercilla, G., Gorini, C., 2014. High-resolution imagery of active faulting offshore Al Hoceima, Northern Morocco. Tectonophysics. https://doi.org/10.1016/j.tecto.2014.06.008

Deschamps, P., Durand, N., Bard, E., Hamelin, B., Camoin, G., Thomas, A.L., Henderson, G.M., Okuno, J., Yokoyama, Y., 2012. Ice-sheet collapse and sea-level rise at the Bolling warming 14,600 years ago. Nature 483, 559-564. https://doi.org/10.1038/nature10902

Ercilla, G., Alonso, B., Baraza, J., 1994. Post-Calabrian sequence stratigraphy of the northwestern Alboran Sea (southwestern Mediterranean). Mar. Geol. 120, 249-265. https://doi.org/10.1016/0025-3227(94)90061-2

Ercilla, G., Alonso, B., Baraza, J., 1992. Sedimentary evolution of the northwestern Alboran Sea during the Quaternary. Geo-Mar. Lett. 12, 144-149. https://doi.org/10.1007/BF02084925

Ercilla, G., Juan, C., Hernández-Molina, F.J., Bruno, M., Estrada, F., Alonso, B., Casas, D., Farran, M., Llave, E., García, M., Vázquez, J.T., D’Acremont, E., Gorini, C., Palomino, D., Valencia, J., El Moumni, B., Ammar, A., 2016. Significance of bottom currents in deep-sea morphodynamics: An example from the Alboran Sea. Mar. Geol. https://doi.org/10.1016/j.margeo.2015.09.007

Font, J., Rousseau, S., Shirasago, B., García-Górriz, E., Haney, R.L., 2002. Mesoscale variability in the Alboran Sea: Synthetic aperture radar imaging of frontal eddies. J. Geophys. Res. Oceans 107, 12-1. https://doi.org/10.1029/2001JC000835 
Galindo-Zaldívar, J., Azzouz, O., Chalouan, A., Pedrera, A., Ruano, P., Ruiz-Constán, A., Sanz de Galdeano, C., Marín-Lechado, C., López-Garrido, A., Anahnah, F., Benmakhlouf, M., 2015. Extensional tectonics, graben development and fault terminations in the eastern Rif $\begin{array}{lllll}\text { (Bokoya-Ras Afraou } & \text { area). }\end{array}$ https://doi.org/10.1016/j.tecto.2015.08.029

Galindo-Zaldívar, J., Chalouan, A., Azzouz, O., Sanz de Galdeano, C., Anahnah, F., Ameza, L., Ruano, P., Pedrera, A., Ruiz-Constán, A., Marín-Lechado, C., Benmakhlouf, M., LópezGarrido, A.C., Ahmamou, M., Saji, R., Roldán-García, F.J., Akil, M., Chabli, A., 2009. Are the seismological and geological observations of the Al Hoceima (Morocco, Rif) 2004 earthquake $(\mathrm{M}=6.3)$ contradictory? Tectonophysics 475, 59-67. https://doi.org/10.1016/j.tecto.2008.11.018

Gensous, B., Tesson, M., Winnock, E., 1986. La marge meridionale de la mer d'alboran: caracteres structuro-sedimentaires et evolution recente. Mar. Geol. 72, 341-370. https://doi.org/10.1016/0025-3227(86)90127-1

Grant, K.M., Rohling, E.J., Bar-Matthews, M., Ayalon, A., Medina-Elizalde, M., Ramsey, C.B., Satow, C., Roberts, A.P., 2012. Rapid coupling between ice volume and polar temperature over the past 150,000 years. Nature 491, 744-747. https://doi.org/10.1038/nature11593

Grant, K.M., Rohling, E.J., Ramsey, C.B., Cheng, H., Edwards, R.L., Florindo, F., Heslop, D., Marra, F., Roberts, A.P., Tamisiea, M.E., Williams, F., 2014. Sea-level variability over five glacial cycles. Nat. Commun. 5, 5076. https://doi.org/10.1038/ncomms6076

Hernández-Molina, F.J., Fernández-Salas, L.M., Lobo, F., Somoza, L., Díaz-del-Río, V., Dias, J.M.A., 2000. The infralittoral prograding wedge: a new large-scale progradational sedimentary body in shallow marine environments. Geo-Mar. Lett. 20, 109-117. https://doi.org/10.1007/s003670000040

Hernández-Molina, F.J., Somoza, L., Rey, J., 1996. Late Pleistocene-Holocene high-resolution sequence analysis on the Alboran Sea continental shelf. Geol. Soc. Lond. Spec. Publ. 117, 139-154. https://doi.org/10.1144/GSL.SP.1996.117.01.08

Hernández-Molina, F.J., Somoza, L., Rey, J., Pomar, L., 1994. Late Pleistocene-Holocene sediments on the Spanish continental shelves: Model for very high resolution sequence stratigraphy. Mar. Geol. 120, 129-174. https://doi.org/10.1016/0025-3227(94)90057-4

Hernández-Molina, F.J., Somoza, L., Vazquez, J.T., Lobo, F., Fernández-Puga, M.C., Llave, E., Díaz-del Río, V., 2002. Quaternary stratigraphic stacking patterns on the continental shelves of the southern Iberian Peninsula: their relationship with global climate and palaeoceanographic changes. Quat. Int., Continental Shelves in the Quaternary: ICGP 396 92, 5-23. https://doi.org/10.1016/S1040-6182(01)00111-2

Hunt, D., Tucker, M.E., 1995. Stranded parasequences and the forced regressive wedge systems tract: deposition during base-level fall-reply. Sediment. Geol. 95, 147-160. https://doi.org/10.1016/0037-0738(94)00123-C

Jouet, G., Berné, S., Rabineau, M., Bassetti, M.A., Bernier, P., Dennielou, B., Sierro, F.J., Flores, J.A., Taviani, M., 2006. Shoreface migrations at the shelf edge and sea-level changes around the Last Glacial Maximum (Gulf of Lions, NW Mediterranean). Mar. Geol. 234, 21-42. https://doi.org/10.1016/j.margeo.2006.09.012

Juan, C., Ercilla, G., Javier Hernández-Molina, F., Estrada, F., Alonso, B., Casas, D., García, M., Farran, M., Llave, E., Palomino, D., Vázquez, J.-T., Medialdea, T., Gorini, C., D’Acremont, E., El Moumni, B., Ammar, A., 2016. Seismic evidence of currentcontrolled sedimentation in the Alboran Sea during the Pliocene and Quaternary: 
Palaeoceanographic implications. https://doi.org/10.1016/j.margeo.2016.01.006

Mar.

Geol.

Kolla, V., Biondi, P., Long, B., Fillon, R., 2000. Sequence stratigraphy and architecture of the Late Pleistocene Lagniappe delta complex, northeast Gulf of Mexico. Geol. Soc. Lond. Spec. Publ. 172, 291-327. https://doi.org/10.1144/GSL.SP.2000.172.01.14

Lafosse, M., d'Acremont, E., Rabaute, A., Mercier de Lépinay, B., Tahayt, A., Ammar, A., Gorini, C., 2017. Evidence of quaternary transtensional tectonics in the Nekor basin (NE Morocco). Basin Res. 29, 470-489. https://doi.org/10.1111/bre.12185

Lambeck, K., Rouby, H., Purcell, A., Sun, Y., Sambridge, M., 2014. Sea level and global ice volumes from the Last Glacial Maximum to the Holocene. Proc. Natl. Acad. Sci. 111, 15296-15303. https://doi.org/10.1073/pnas.1411762111

Lea, D.W., Martin, P.A., Pak, D.K., Spero, H.J., 2002. Reconstructing a 350 ky history of sea level using planktonic $\mathrm{Mg} / \mathrm{Ca}$ and oxygen isotope records from a Cocos Ridge core. Quat. Sci. Rev., EPILOG 21, 283-293. https://doi.org/10.1016/S0277-3791(01)00081-6

Lisiecki, L.E., Raymo, M.E., 2005. A Pliocene-Pleistocene stack of 57 globally distributed $\begin{array}{llll}\text { benthic } \delta 180 \quad \text { records. } & \text { Paleoceanography 20, PA1003. }\end{array}$ https://doi.org/10.1029/2004PA001071

Lobo, F.J., Goff, J.A., Mendes, I., Bárcenas, P., Fernández-Salas, L.M., Martín-Rosales, W., Macías, J., Río, V.D. del, 2014. Spatial variability of prodeltaic undulations on the Guadalfeo River prodelta: support to the genetic interpretation as hyperpycnal flow deposits. Mar. Geophys. Res. 1-25. https://doi.org/10.1007/s11001-014-9233-9

Lobo, F.J., Maldonado, A., Hernández-Molina, F.J., Fernández-Salas, L.M., Ercilla, G., Alonso, B., 2008. Growth patterns of a proximal terrigenous margin offshore the Guadalfeo River, northern Alboran Sea (SW Mediterranean Sea): glacio-eustatic control and disturbing tectonic factors. Mar. Geophys. Res. 29, 195-216. https://doi.org/10.1007/s11001-0089058-5

Lobo, F.J., Ridente, D., 2014. Stratigraphic architecture and spatio-temporal variability of highfrequency (Milankovitch) depositional cycles on modern continental margins: An overview. Mar. Geol., 50th Anniversary Special Issue 352, 215-247. https://doi.org/10.1016/j.margeo.2013.10.009

Lobo, F.J., Tesson, M., Gensous, B., 2004. Stratral architectures of late Quaternary regressivetransgressive cycles in the Roussillon Shelf (SW Gulf of Lions, France). Mar. Pet. Geol. 21, 1181-1203. https://doi.org/10.1016/j.marpetgeo.2004.07.003

Martínez-Carreño, N., García-Gil, S., Cartelle, V., 2017. An unusual Holocene fan-shaped subaqueous prograding body at the back of the Cíes Islands ridge (Ría de Vigo, NW Spain): Geomorphology, facies and stratigraphic architecture. Mar. Geol. 385, 13-26. https://doi.org/10.1016/j.margeo.2016.11.015

Martinez-Martos, M., Galindo-Zaldivar, J., Lobo, F.J., Pedrera, A., Ruano, P., Lopez-Chicano, M., Ortega-Sánchez, M., 2016. Buried marine-cut terraces and submerged marine-built terraces: The Carchuna-Calahonda coastal area (southeast Iberian Peninsula). Geomorphology 264, 29-40. https://doi.org/10.1016/j.geomorph.2016.04.010

Martorelli, E., Chiocci, F.L., Orlando, L., 2010. Imaging continental shelf shallow stratigraphy by using different high-resolution seismic sources: an example from the CalabroTyrrhenian margin (Mediterranean Sea). Braz. J. Oceanogr. 58, 55-66. https://doi.org/10.1590/S1679-87592010000500006

Miller, M.S., Allam, A.A., Becker, T.W., Di Leo, J.F., Wookey, J., 2013. Constraints on the tectonic evolution of the westernmost Mediterranean and northwestern Africa from shear 
wave splitting analysis. Earth Planet. Sci. Lett. 375, 234-243. https://doi.org/10.1016/j.eps1.2013.05.036

Mitchum, R.M.J., Wagoner, J.C.V., 1991. High-frequency sequences and their stacking patterns: sequence-stratigraphic evidence of high-frequency eustatic cycles. Sediment. Geol. 70, 131-160. https://doi.org/0037-0738/91/\$03.50

Mulder, T., Syvitski, J.P.M., Migeon, S., Faugères, J.-C., Savoye, B., 2003. Marine hyperpycnal flows: initiation, behavior and related deposits. A review. Mar. Pet. Geol., Turbidites: Models and Problems 20, 861-882. https://doi.org/10.1016/j.marpetgeo.2003.01.003

Pascual, A., Ruiz, S., Olita, A., Troupin, C., Claret, M., Casas, B., Mourre, B., Poulain, P.-M., Tovar-Sanchez, A., Capet, A., Mason, E., Allen, J.T., Mahadevan, A., Tintoré, J., 2017. A multiplatform experiment to unravel meso- and submesoscale processes in an intense front (AlborEx). Front. Mar. Sci. 4. https://doi.org/10.3389/fmars.2017.00039

Paull, C.K., Caress, D.W., Ussler, W., Lundsten, E., Meiner-Johnson, M., 2011. High-resolution bathymetry of the axial channels within Monterey and Soquel submarine canyons, offshore central California. Geosphere 7, 1077-1101. https://doi.org/10.1130/GES00636.1

Pepe, F., Bertotti, G., Ferranti, L., Sacchi, M., Collura, A.M., Passaro, S., Sulli, A., 2014. Pattern and rate of post-20 ka vertical tectonic motion around the Capo Vaticano Promontory (W Calabria, Italy) based on offshore geomorphological indicators. Quat. Int., Relative sea level changes: Signature on continental shelves, changing coastlines, and implications for coastal morphodynamics 332, 85-98. https://doi.org/10.1016/j.quaint.2013.11.012

Plint, A.G., Nummedal, D., 2000. The falling stage systems tract: recognition and importance in sequence stratigraphic analysis. Geol. Soc. Lond. Spec. Publ. 172, 1-17. https://doi.org/10.1144/GSL.SP.2000.172.01.01

Posamentier, H., Allen, G.P., 1993. The "Healing Phase" -- a Commonly Overlooked Component of the Transgressive Systems. Presented at the AAPG Annual Convention, AAPG Search and Discovery, New Orleans, Louisiana.

Posamentier, H.W., Allen, G.P., James, D.P., Tesson, M., 1992. Forced regressions in a sequence stratigraphic framework concepts Examples and exploration significance. Am. Assoc. Pet. Geol. Bull. 1787-1809.

Posamentier, H.W., Morris, W.R., 2000. Aspects of the stratal architecture of forced regressive deposits. Geol. Soc. Lond. Spec. Publ. 172, 19-46. https://doi.org/10.1144/GSL.SP.2000.172.01.02

Poujol, A., Ritz, J.-F., Tahayt, A., Vernant, P., Condomines, M., Blard, P.-H., Billant, J., Vacher, L., Tibari, B., Hni, L., Koulali, A., 2014. Active tectonics of the Northern Rif (Morocco) from geomorphic and geochronological data. J. Geodyn., SI : Geodynamic evolution of the Alboran domain 77, 70-88. https://doi.org/10.1016/j.jog.2014.01.004

Rabineau, M., 2001. Un modèle géométrique et stratigraphique des séquences de dépôts quaternaires sur la marge du Golfe du Lion: enregistrement des cycles climatiques de 100 000 ans. Université Renne 1, Rennes.

Rabineau, M., Berné, S., Aslanian, D., Olivet, J.-L., Joseph, P., Guillocheau, F., Bourillet, J.-F., Ledrezen, E., Granjeon, D., 2005. Sedimentary sequences in the Gulf of Lion: A record of 100,000 years climatic cycles. Mar. Pet. Geol. 22, 775-804. https://doi.org/10.1016/j.marpetgeo.2005.03.010

Rabineau, M., Berné, S., Ledrezen, É., Lericolais, G., Marsset, T., Rotunno, M., 1998. 3D architecture of lowstand and transgressive Quaternary sand bodies on the outer shelf of 
the Gulf of Lion, France. Mar. Pet. Geol. 15, 439-452. https://doi.org/10.1016/S02648172(98)00015-4

Ridente, D., Petrungaro, R., Falese, F., Chiocci, F.L., 2012. Middle-Upper Pleistocene record of 100-ka depositional cycles on the Southern Tuscany continental margin (Tyrrhenian Sea, Italy). Mar. Geol. 326-328, 1-13. https://doi.org/10.1016/j.margeo.2012.09.003

Ridente, D., Trincardi, F., 2002. Eustatic and tectonic control on deposition and lateral variability of Quaternary regressive sequences in the Adriatic basin (Italy). Mar. Geol. 184, 273-293. https://doi.org/10.1016/S0025-3227(01)00296-1

Ridente, D., Trincardi, F., Piva, A., Asioli, A., 2009. The combined effect of sea level and supply during Milankovitch cyclicity: Evidence from shallow-marine $\delta 180$ records and sequence architecture (Adriatic margin). Geology 37, 1003-1006. https://doi.org/10.1130/G25730A.1

Stich, D., Mancilla, F. d. L., Baumont, D., Morales, J., 2005. Source analysis of the Mw 6.32004 Al Hoceima earthquake (Morocco) using regional apparent source time functions. J. Geophys. Res. 110. https://doi.org/10.1029/2004JB003366

Symons, W.O., Sumner, E.J., Talling, P.J., Cartigny, M.J.B., Clare, M.A., 2016. Large-scale sediment waves and scours on the modern seafloor and their implications for the prevalence of supercritical flows. Mar. Geol. 371, 130-148. https://doi.org/10.1016/j.margeo.2015.11.009

Tesson, M., Gensous, B., 1989. Les bases d'une stratigraphie sismique du Néogène post-nappes en mer d'Alboran, au large du Maroc. Implications structurales et paléogéographiques. J. Afr. Earth Sci. Middle East 9, 421-433. https://doi.org/10.1016/0899-5362(89)90026-2

Tesson, M., Gensous, B., Allen, G.P., Ravenne, C., 1990. Late Quaternary Lowstand Wedges on the Rhône Continental Shelf, France. Mar. Geol. 91, 325-332. https://doi.org/10.1016/0025-3227(90)90053-M

Tesson, M., Gensous, B., Lambraimi, M., 1987. Seismic analysis of the southern margin of the Alboran Sea. J. Afr. Earth Sci. 1983 6, 813-821. https://doi.org/10.1016/08995362(87)90038-8

Urgeles, R., Cattaneo, A., Puig, P., Liquete, C., Mol, B., Amblàs, D., Sultan, N., Trincardi, F., 2011. A review of undulated sediment features on Mediterranean prodeltas: distinguishing sediment transport structures from sediment deformation. Mar. Geophys. Res. 32, 49-69. https://doi.org/10.1007/s11001-011-9125-1

Van der Woerd, J., Dorbath, C., Ousadou, F., Dorbath, L., Delouis, B., Jacques, E., Tapponnier, P., Hahou, Y., Menzhi, M., Frogneux, M., Haessler, H., 2014. The Al Hoceima Mw 6.4 earthquake of 24 February 2004 and its aftershocks sequence. J. Geodyn. 77, 89-109. https://doi.org/10.1016/j.jog.2013.12.004

Viúdez, A., Pinot, J.-M., Haney, R.L., 1998. On the upper layer circulation in the Alboran Sea. J. Geophys. Res. Oceans 103, 21653-21666. https://doi.org/10.1029/98JC01082

Viúdez, Á., Tintoré, J., Haney, R.L., 1996. Circulation in the Alboran Sea as Determined by Quasi-Synoptic Hydrographic Observations. Part I: Three-Dimensional Structure of the Two Anticyclonic Gyres. J. Phys. Oceanogr. 26, 684-705. https://doi.org/10.1175/15200485(1996)026<0684:CITASA > 2.0.CO;2

Waelbroeck, C., Labeyrie, L., Michel, E., Duplessy, J.C., McManus, J.F., Lambeck, K., Balbon, E., Labracherie, M., 2002. Sea-level and deep water temperature changes derived from benthic foraminifera isotopic records. Quat. Sci. Rev., EPILOG 21, 295-305. https://doi.org/10.1016/S0277-3791(01)00101-9 
Zecchin, M., Catuneanu, O., 2013. High-resolution sequence stratigraphy of clastic shelves I: Units and bounding surfaces. Mar. Pet. Geol. 39, 1-25. https://doi.org/10.1016/j.marpetgeo.2012.08.015 and variability in the geometry of transgressive erosional surfaces in high-gradient shelves: The case of the Ionian Calabrian margin (southern Italy). Mar. Geol. 281, 43-58. https://doi.org/10.1016/j.margeo.2011.02.003

Zecchin, M., Ceramicola, S., Lodolo, E., Casalbore, D., Chiocci, F.L., 2015a. Episodic, rapid sealevel rises on the central Mediterranean shelves after the Last Glacial Maximum: A review. Mar. Geol. 369, 212-223. https://doi.org/10.1016/j.margeo.2015.09.002

Zecchin, M., Ceramicola, S., Lodolo, E., Casalbore, D., Chiocci, F.L., 2015b. Episodic, rapid sea-level rises on the central Mediterranean shelves after the Last Glacial Maximum: A review. Mar. Geol. 369, 212-223. https://doi.org/10.1016/j.margeo.2015.09.002 
291

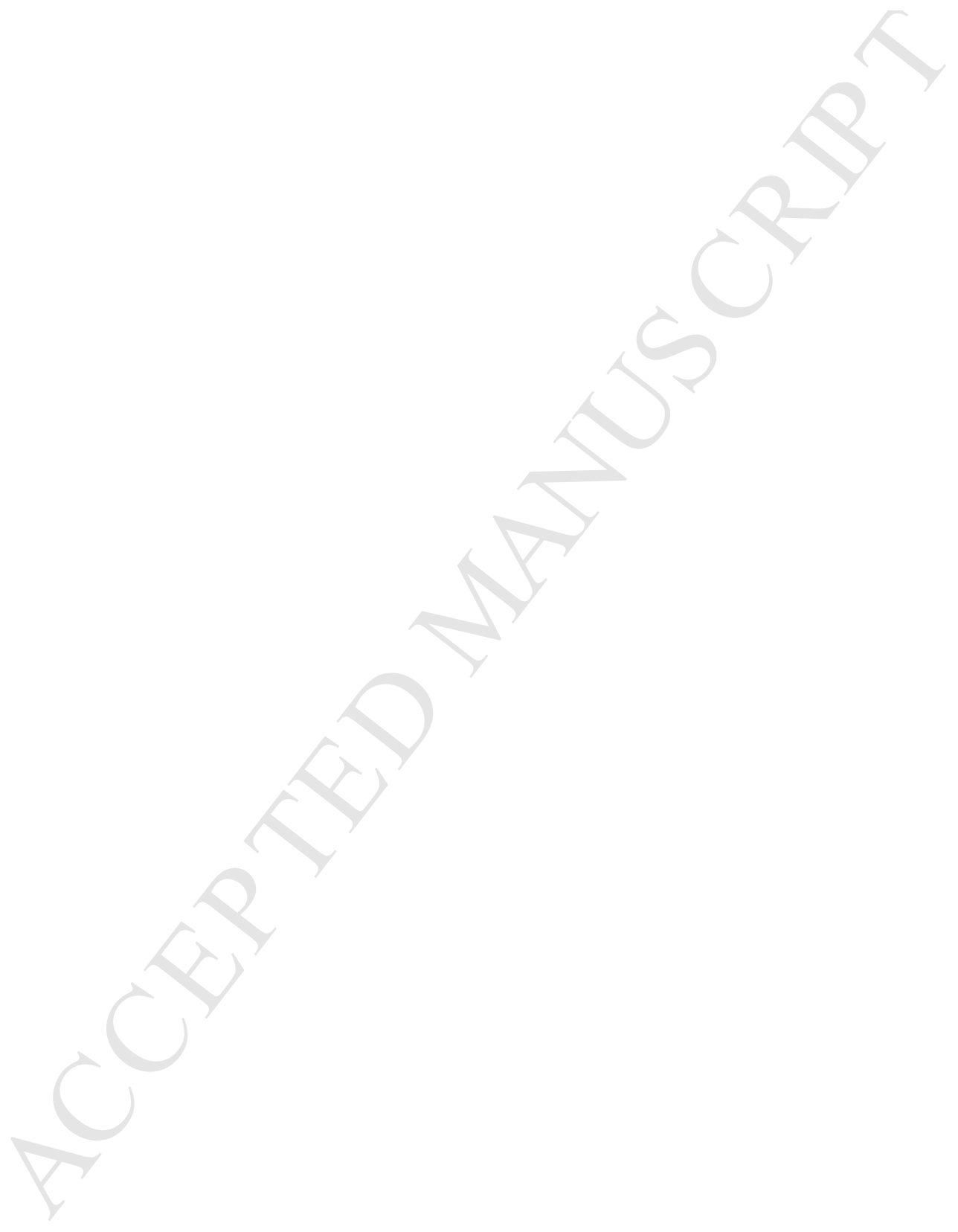


Table 1

\begin{tabular}{|c|c|c|c|c|}
\hline $\begin{array}{l}\text { Seismic sub- } \\
\quad \text { units }\end{array}$ & Geometry & Seismic facies & $\begin{array}{l}\text { Position on the } \\
\text { shelf [ } \\
\text { Bathymetry of } \\
\text { the rooftop] }\end{array}$ & Example of geometry \\
\hline $\begin{array}{c}\text { Low angle } \\
\text { prograding } \\
\text { seismic sub- } \\
\text { units } \\
\text { [u1b to u5b] }\end{array}$ & $\begin{array}{l}\text { Wedge of low angle }\left(0^{\circ}-\right. \\
\left.1.5^{\circ}\right) \text { continuous and even } \\
\text { reflector with coastal } \\
\text { onlap and local distal } \\
\text { downlap }\end{array}$ & $\begin{array}{l}\text { Low amplitude and low } \\
\text { frequency }\end{array}$ & $\begin{array}{l}\text { Inner to outer } \\
\text { shelf }\end{array}$ & Seaward \\
\hline $\begin{array}{c}\text { Distal } \\
\text { hummocky } \\
\text { seismic sub- } \\
\text { units } \\
{[u 3 d, \text { u5d] }} \\
\end{array}$ & $\begin{array}{l}\text { Wedge of hummocky } \\
\text { reflectors with marine } \\
\text { onlap }\end{array}$ & $\begin{array}{l}\text { Medium amplitude and } \\
\text { frequency }\end{array}$ & $\begin{array}{l}\text { Upper } \\
\text { continental slope }\end{array}$ & 2 \\
\hline $\begin{array}{c}\text { High angle } \\
\text { prograding } \\
\text { shelf edge } \\
\text { wedge[ulc to } \\
\text { u5c] } \\
\end{array}$ & $\begin{array}{l}\text { Wedge of high angle } \\
\text { parallel reflectors }\left(2^{\circ}-6^{\circ}\right) \\
\text { with landward toplap } \\
\text { termination }\end{array}$ & $\begin{array}{l}\text { Medium amplitude } \\
\text { medium frequency }\end{array}$ & $\begin{array}{l}\text { Outer shelf } \\
{[-107 \mathrm{~m} ;-125 \mathrm{~m}]}\end{array}$ & \\
\hline $\begin{array}{c}\text { Distal } \\
\text { aggrading } \\
\text { wedge } \\
{[u 2 a \text { to } 46 a]}\end{array}$ & $\begin{array}{l}\text { Wedge of low angle }\left(0^{\circ}-\right. \\
\left.1.5^{\circ}\right) \text { parallel reflectors } \\
\text { with concordant landward } \\
\text { termination to marine } \\
\text { onlap }\end{array}$ & $\begin{array}{l}\text { Low amplitude and low } \\
\text { frequency }\end{array}$ & $\begin{array}{l}\text { Upper } \\
\text { continental slope } \\
\text { to shelf edge }\end{array}$ & \\
\hline $\begin{array}{c}\text { High angle } \\
\text { prograding } \\
\text { mid-shelf } \\
\text { wedge } \\
{[\text { [ubb] }} \\
\end{array}$ & $\begin{array}{l}\text { Wedge of high angle to low } \\
\text { angle }\left(0.1^{\circ}-5^{\circ}\right) \text { sigmoid } \\
\text { reflectors diverging } \\
\text { seaward }\end{array}$ & $\begin{array}{l}\text { High amplitude with high } \\
\text { frequency to medium } \\
\text { amplitude with medium } \\
\text { frequency }\end{array}$ & $\begin{array}{l}\text { Middle shelf } \\
{[-80 \mathrm{~m}]}\end{array}$ & \\
\hline $\begin{array}{l}\text { Wavy mid- } \\
\text { shelf unit } \\
\quad \text { [u6c] }\end{array}$ & $\begin{array}{l}\text { Wedge of wavy subparallel } \\
\text { reflectors pinching } \\
\text { seaward around }-110 \mathrm{~m} \\
\text { deep }\end{array}$ & $\begin{array}{l}\text { Middle amplitude low } \\
\text { frequency }\end{array}$ & $\begin{array}{l}\text { Middle shelf to } \\
\text { outer shelf [110; } \\
-4 \mathrm{~m}]\end{array}$ & \\
\hline
\end{tabular}



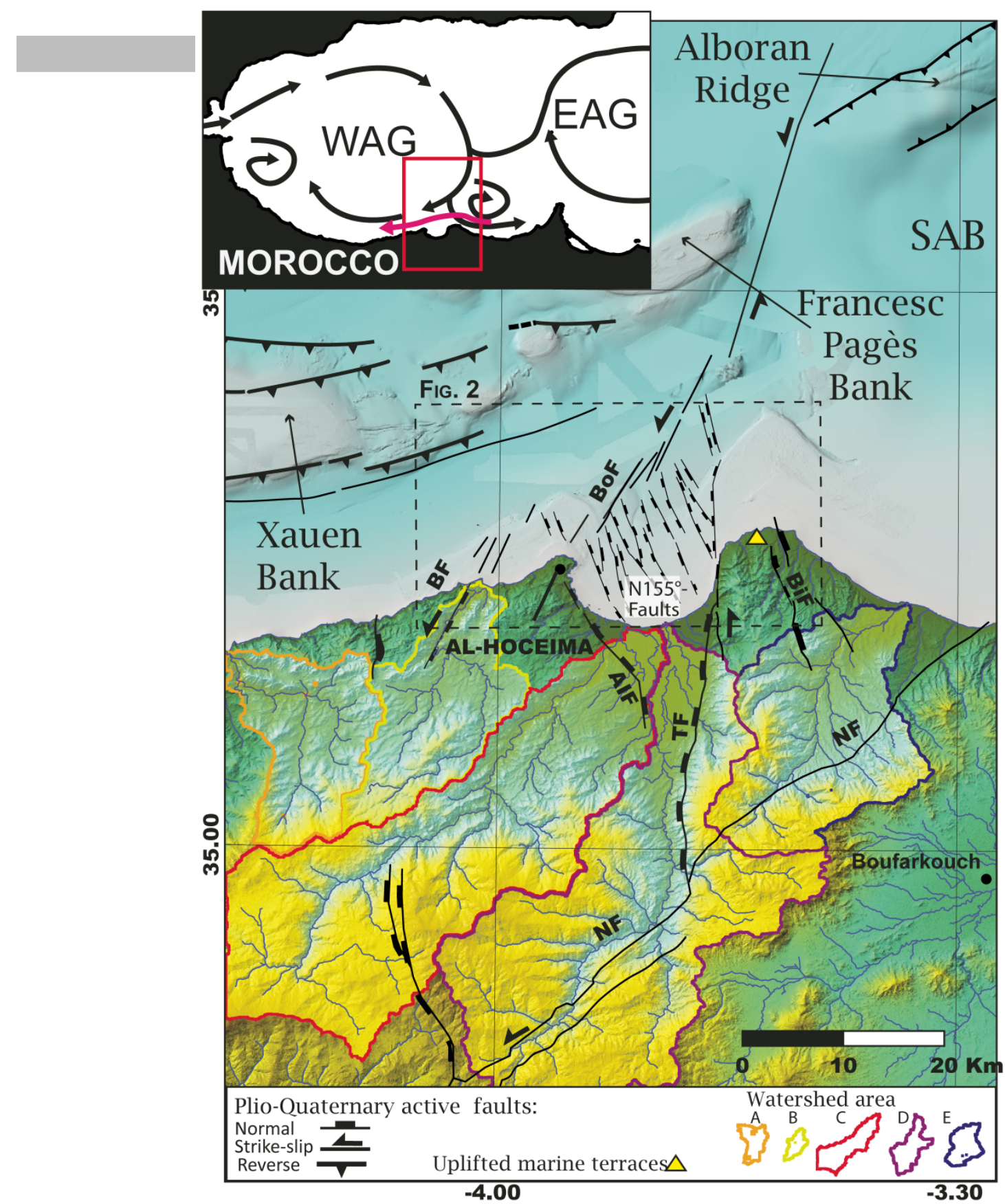

Figure 1. Topography and bathymetry of the study area. Onshore: the topography is extracted from the ASTER GDEM (http://gdem.ersdac.jspacesystems.or.jp/). A, B, C, D and E: watershed area computed with Globalmapper@. A: Oued Nekor watershed, B: Oued Rhîs watershed. C: Oued Tarmast watershed; D: unnamed oued watershed, E Oued Amekrane watershed. Tectonic structures are from Van der Woert et al. (2015) and Poujol et al. (2015). Offshore: bathymetry from SARAS and MARLOBO-2 surveys over the GEBCO bathymetry (https://www.gebco.net/). Offshore tectonic structures are from Lafosse et al. (2016). Legend: BF, Boussekour fault; Bof, Bokkoya fault; BiF: Boudinar fault; IAF: Ajdir-Imzouren fault; TF: Trougout fault, NF: Nekor fault; SAB: South Alboran Basin; Black dashed rectangle: study area. Upper left inset: simplified oceanographic setting of the Alboran Sea. Red rectangle: study area. Black arrows: Atlantic water mass circulation (Font et al. 2002); Pink arrow: shelf water mass circulation (Ercilla et al. 2016); EAG: Eastern Alboran Gyre; WAG: Western Alboran Gyre. Projection: UTM N30, datum WGS1984. 


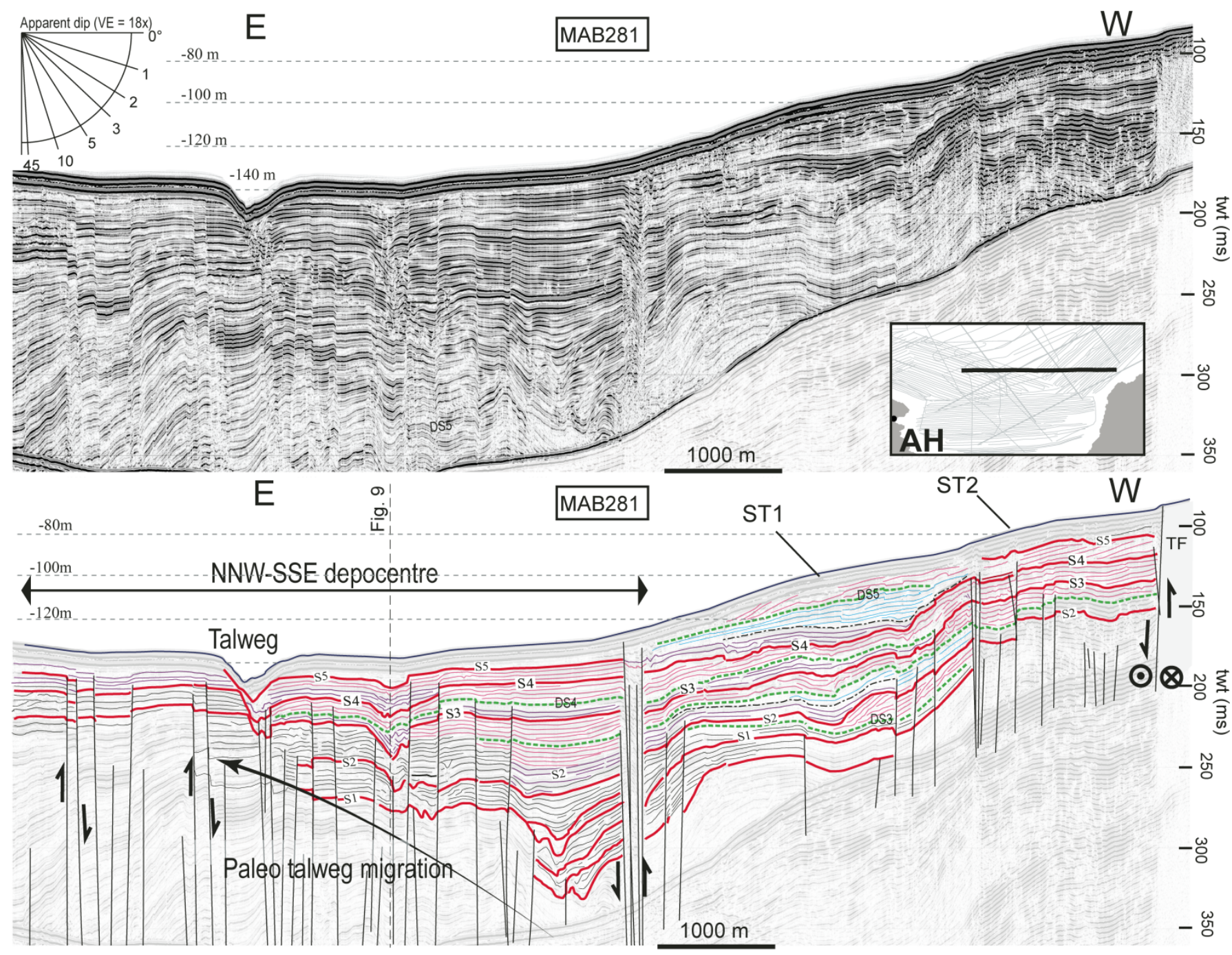

Figure 10. MAB281 seismic profile and the corresponding line drawing in the continental upper slope of the central sector. Red lines, S1 to S5, refer to regional unconformities; purple reflectors refer to distal aggrading wedges; pink reflectors refer to prograding high angle wedge on the continental shelf and to distal hummocky wedge on the upper slope; light blue reflectors refer to low angle prograding wedge; light green reflectors refer to mid-shelf prograding high angle wedge; brown reflectors refer to wavy mid-shelf wedge. TF: Trougout fault. AH: Al-Hoceima. The position of the seismic line in figure 9 is projected on the MAP218 profile. Note the pervasive faulting affecting the continental upper slope. 

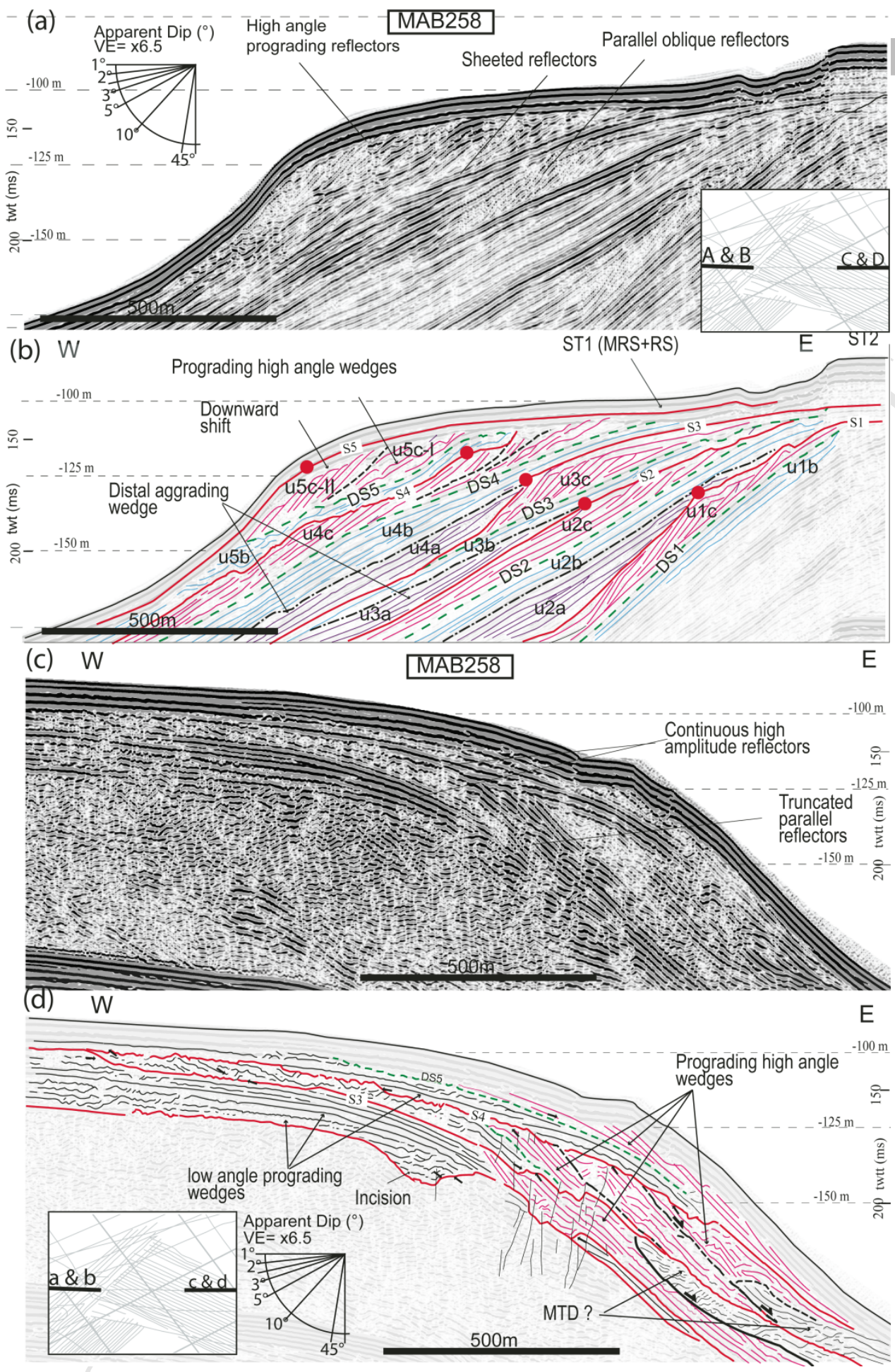

Figure 11. Selected seismic profile showing the seismic architecture of the Ras Tarf continental shelf and slope (eastern sector of the shelf). (a) and (b) Western portion of the MAB258 seismic profile and the corresponding line drawing. (c) and (d) Eastern portion of the MAB258 seismic profile and the corresponding line drawing. Insets: positions of the seismic section and vertical exaggeration. Grey surface: emerged areas; Red lines: S1 to S5 refer to regional unconformities; dashed green line: downlap surfaces DS1 to DS5; dashed black line: local unconformity below and above the S and DS surfaces, respectively; black dotted dashed line to local unconformity above and below the S and DS surfaces, respectively; purple reflectors refer to distal aggrading wedges; pink reflectors refer to prograding-high-angle wedge on the continental shelf; light blue reflectors refer to low angle prograding wedge; vertical black lines, faults; red dot: offlap break. 

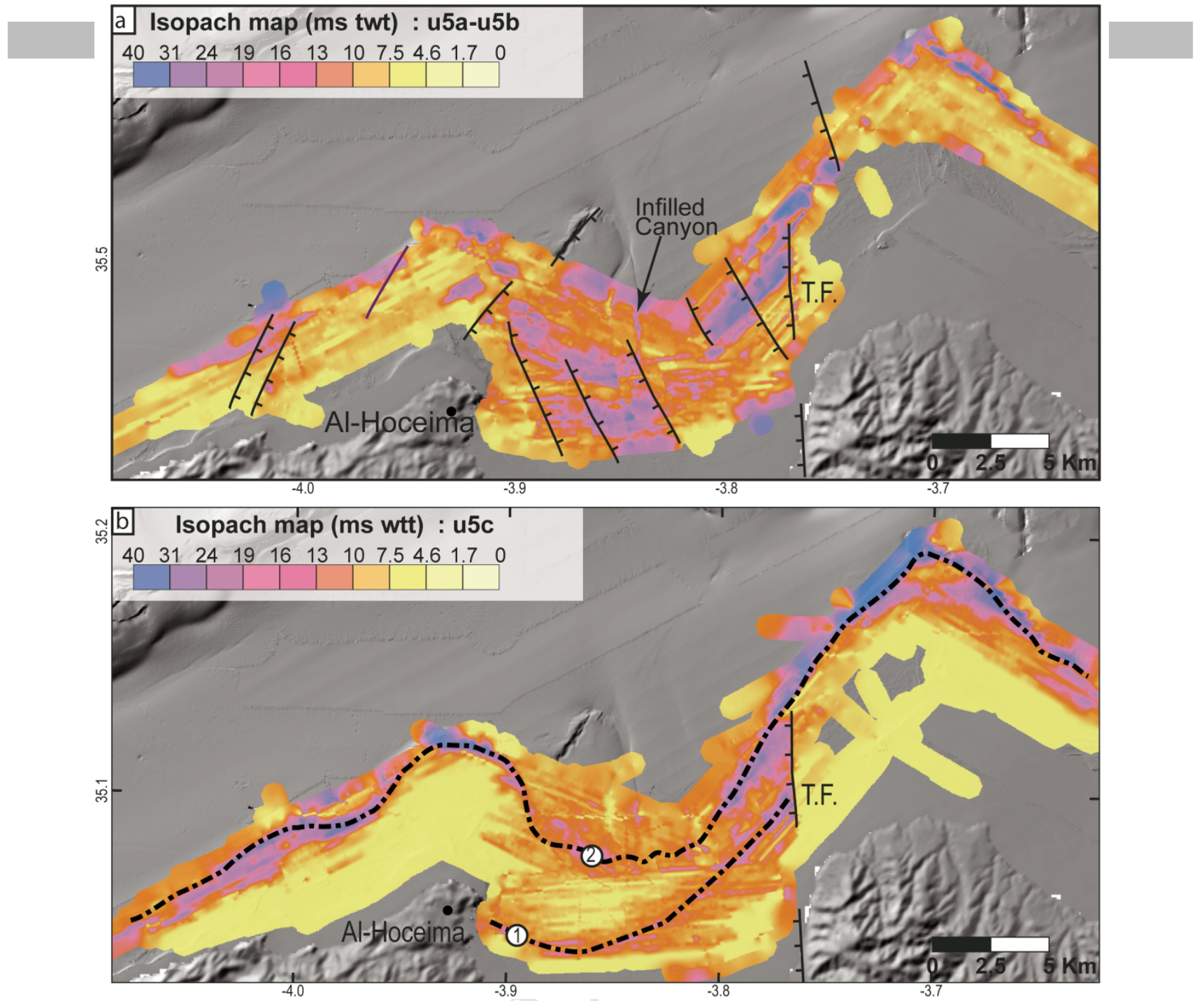

Figure 12. (a) Thickness of the merged u5a and u5b seismic sub-units. These seismic sub-units are merged because u5a cannot be laterally distinguished locally from $\mathrm{u} 5 \mathrm{~b}$ in the continental upper slope due to syn-deformation deposition. Note the NW-SE

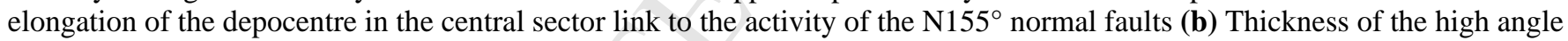
prograding wedge u5c. The dashed dotted lines (1) and (2) indicate the successive positions of the offlap breaks u5c1 and u5c2 seismic sub-units. The sharp transition from thick deposits to thin deposits between $3.8^{\circ} \mathrm{W}$ and $3.76^{\circ} \mathrm{W}$ is the consequence of the Trougout fault activity (TF). Black barbed lines show the traces of the faults. To produce these maps, we use the regional unconformities (S4 and S5 surfaces) and the downlap DS5. Other stratigraphic surfaces cannot be followed laterally with a sufficient confidence due to the numerous faults in the area. 


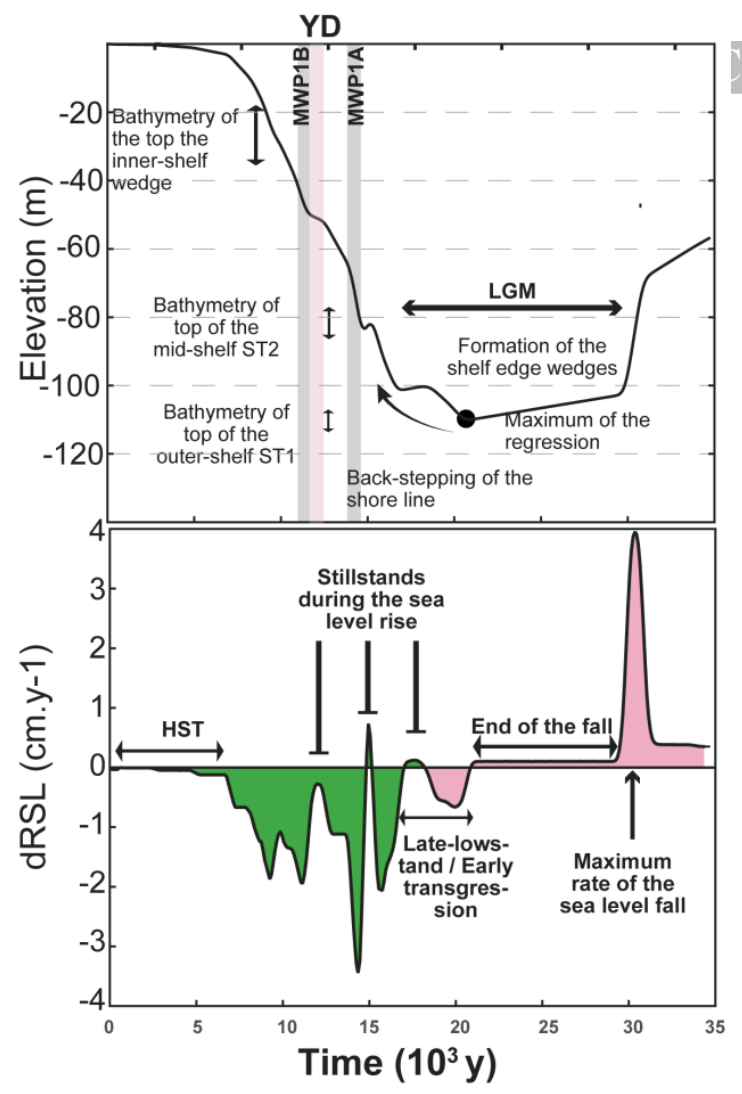

Figure 13. Relative sea level at Gibraltar since $35 \mathrm{ky}$ (top), and the corresponding first derivative (bottom). The curve was computed from the ice-volume equivalent sea level (Lambeck et al. 2014) and assuming ESL=1.23*RSL at Gibraltar (Rohling et al. 2014). MWP-1A and MWP-1B, Main Water Pulse 1A and 1B; YD, younger Drias. 


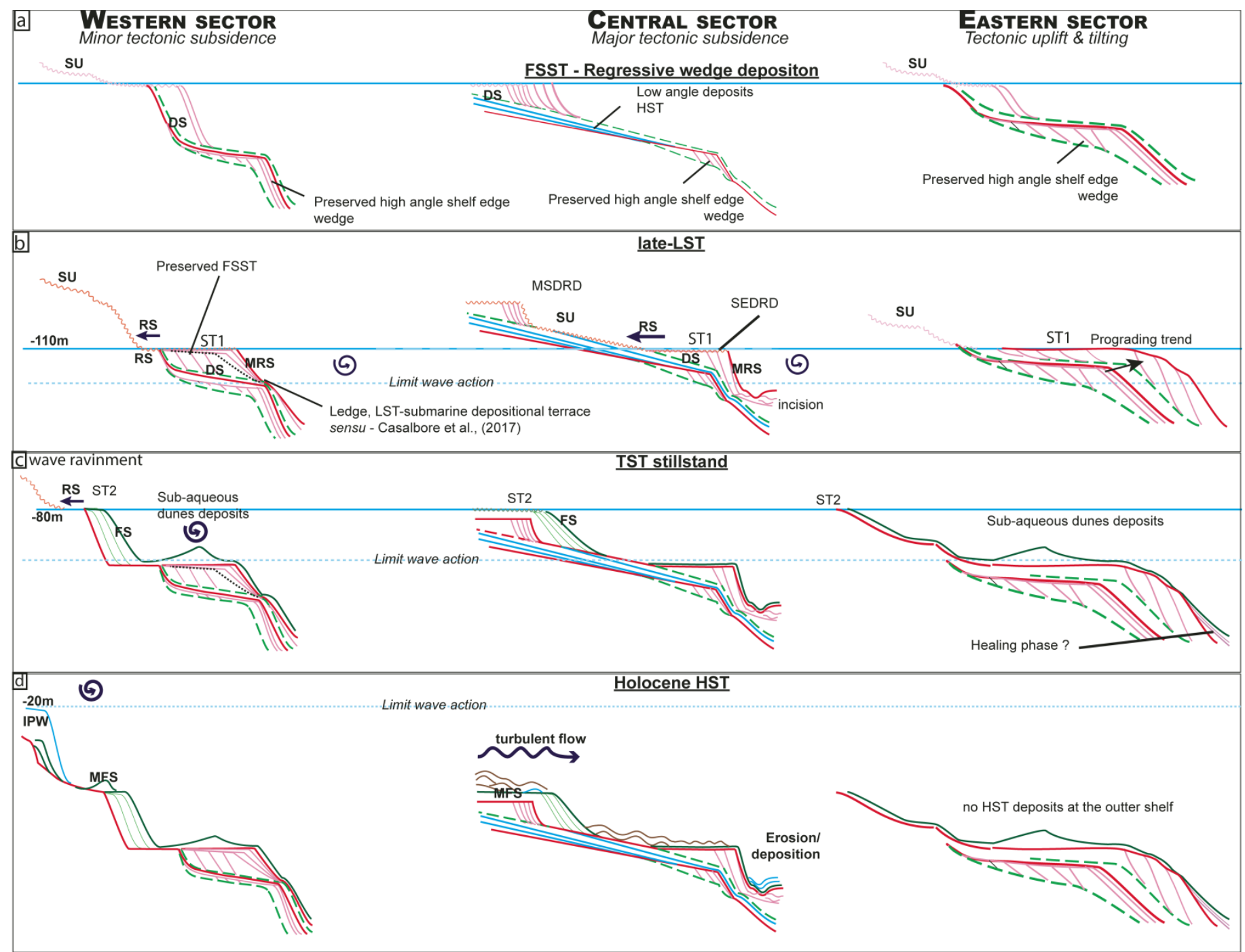

Figure 14. Schematic diagram of the evolution of the study area at key timesteps around the LGM: (a) around MIS3; (b) formation of the sub-marine terrace 1 (ST1) during the LGM; (c) formation of the sub-marine terrace 2 during the stillstand of the sea level rise around $-15 \mathrm{ky}$ and (d) formation of the inner-shelf wedges (open shelf) and of the pro-deltaïc undulations (Nekor basin) during the Holocene late transgression and highstand. The colors refer to the seismic sub-units illustated in the previous figures. Horizontal blue line: sea level; light blue dashed horizontal line: limit of wave action; dark blue spiral: alongshore current; dark blue undulated arrows: fluvial influence; horizontal black arrow: cliff retreat under wave ravinement; MSDRD: mid-shelf detached regressive deposit; SEDRD: shelf edge detached regressive deposits. SU: sub-aerial unconformity; RS: ravinement surface; MRS: maximum regressive surface; DS: downlap surface; FS: flooding surface; IPW: infralittoral prograding wedge; MFS: maximum flooding surface. 


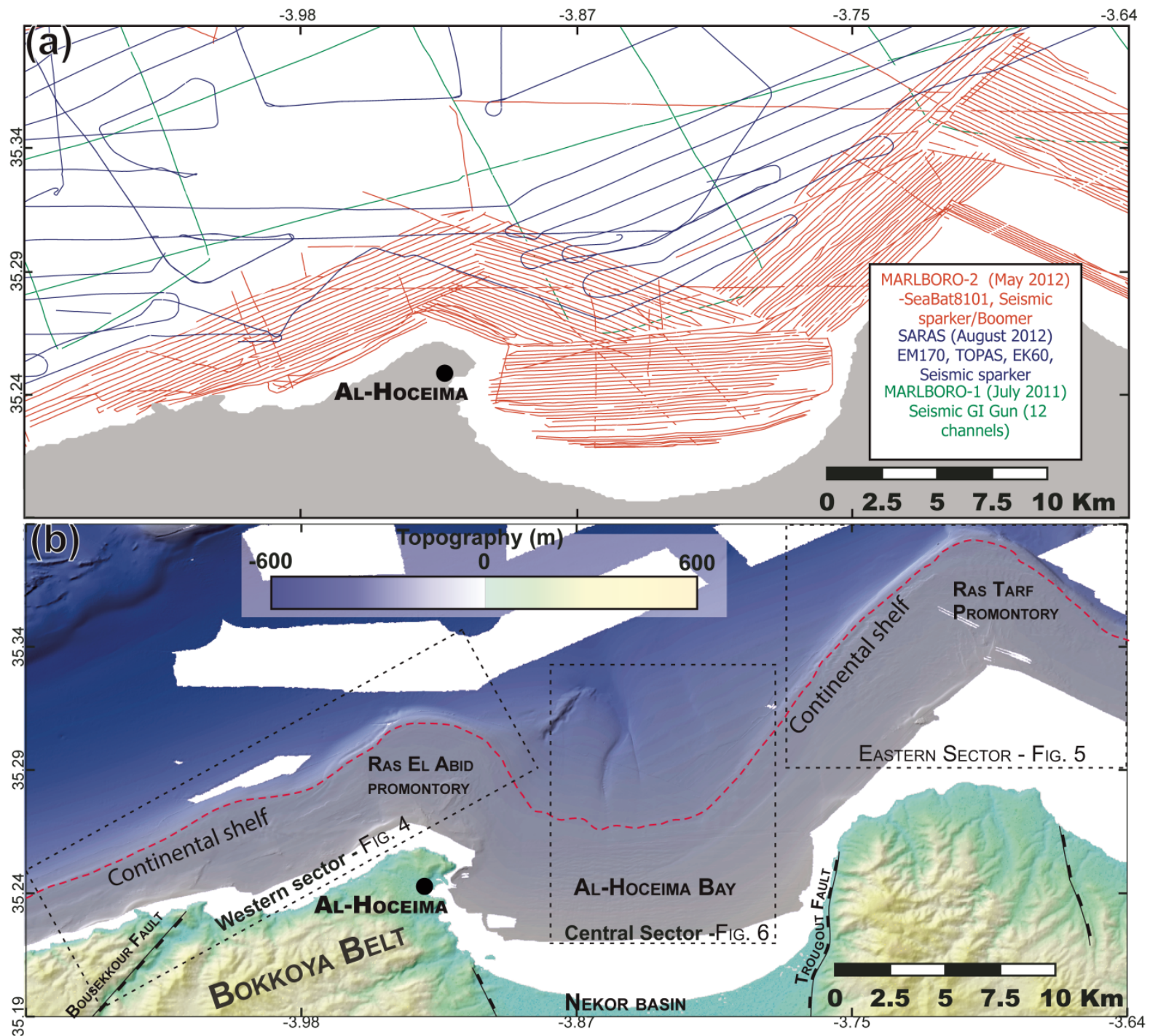

Figure 2. (a) Location of the seismic reflection profiles acquired during the MARLBORO-1, MARLBORO-2 and SARAS surveys. (b) Physiographic features of the study area. Black dashed rectangles: positions of Figs. 4, 5 and 6. 


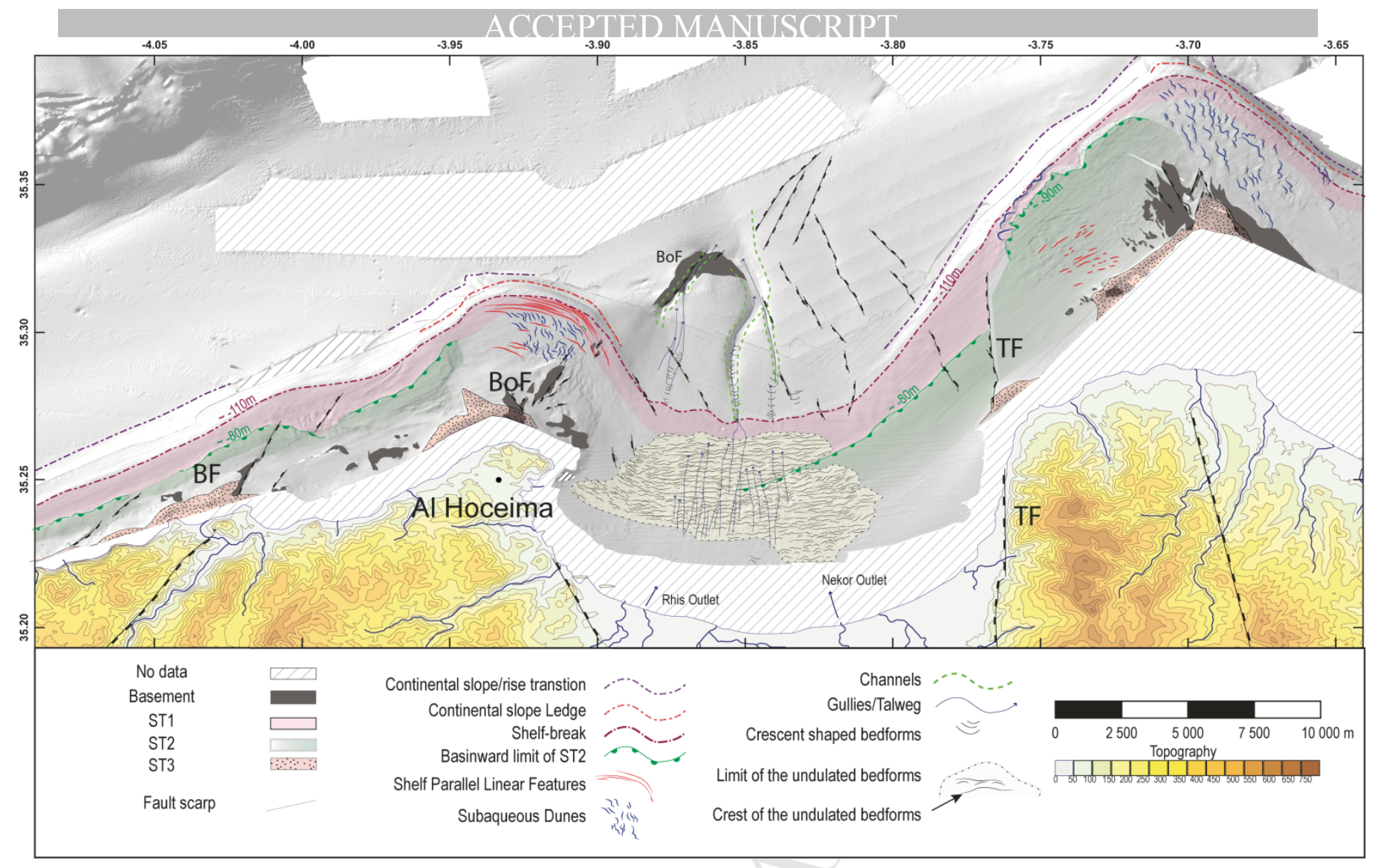

Figure 3. Geomorphological map showing the main morphological features of the study area. Onshore: contour lines of the topography. BF: Bousekkour fault; BoF: Bokkoya fault; TF: Trougout fault. The faults affecting the seafloor are described in Lafosse et al., 2017. 

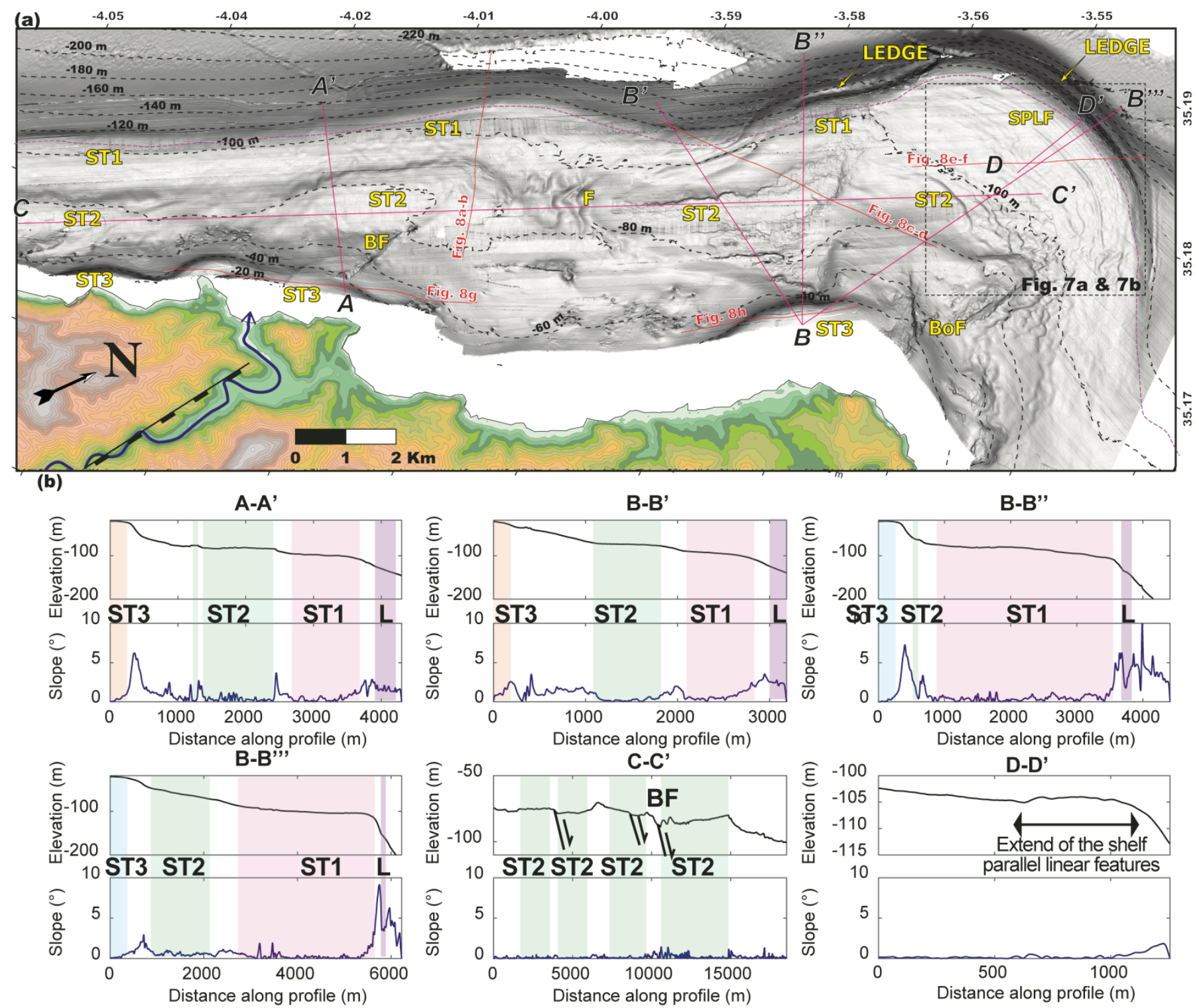

Figure 4. (a) Slope map and isobaths showing the morphological and structural features of the western sector of the study area.

Dashed black lines: isobaths. Dashed black rectangle: position of Figs.7a and 7b. Orange lines refer to position of the seismic lines in Fig. 8. Magenta lines refer to the position of the topograpahic profiles in (b). BF: Bousekkour fault; BoF: Bokkoya Fault; F: fault; SPLF: slope parallel linear features; ST: sub-marine terraces. (b) topographic profiles (top), and corresponding slope gradient profiles (bottom). A-A', B-B', B-B', and B-B',' show the morphology of the continental shelf and of the upper slope. CC' show the morphology of ST2 along the continental shelf and its offset by the Boussekour fault, BF. D-D' show the morphology of the slope parallel linear features. The light purple patches indicate the positions of the ledges, L; the pink patches indicate the position of ST1; the green patches indicate the position of ST2; the light orange patches the position of ST3. 

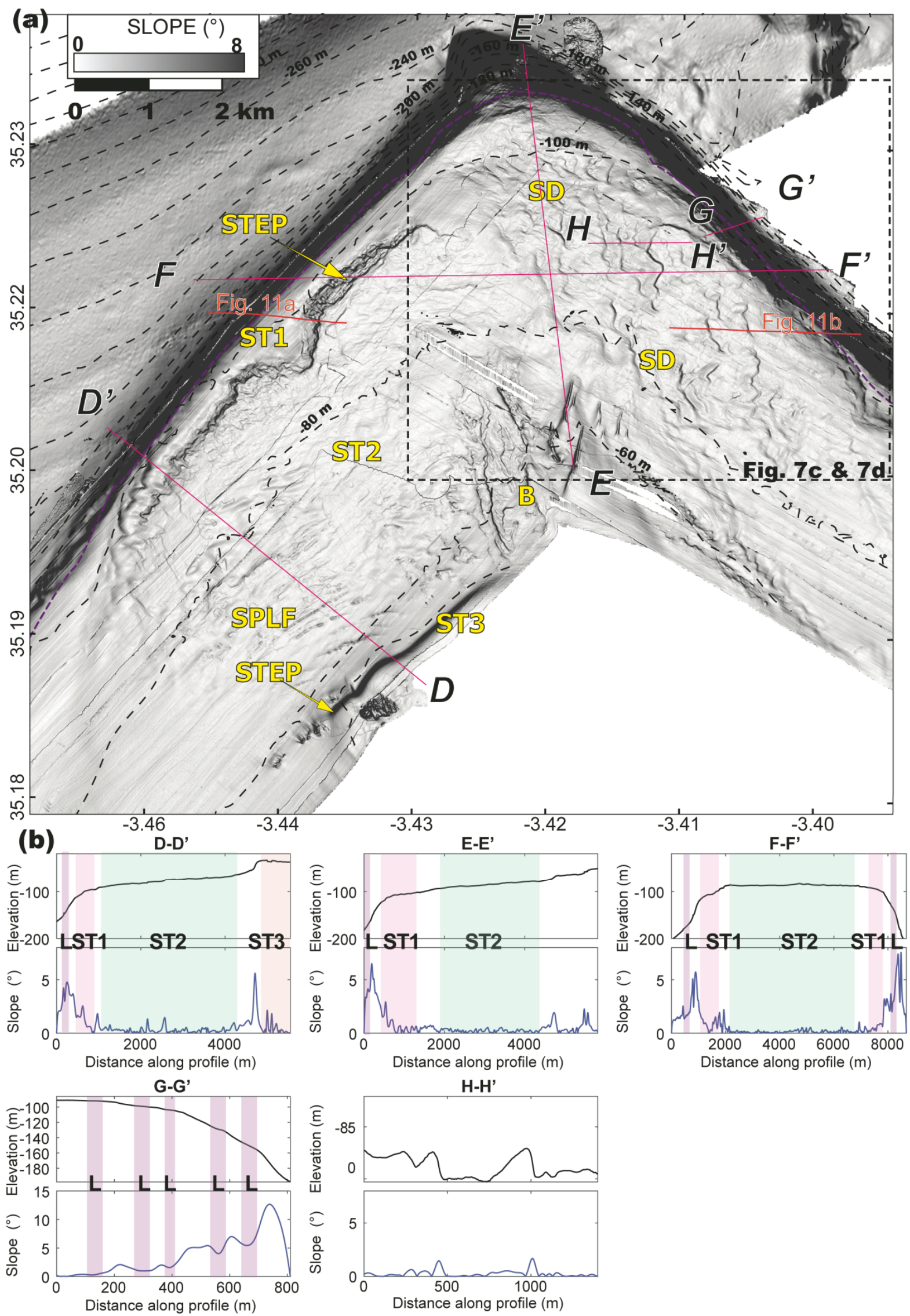

Figure 5. a) Slope map and isobaths showing the morphological and structural features of the eastern sector (Ras Tarf Promontory) of the study area. Dashed black lines: isobaths. Dashed black rectangle: position of Figs.7c and 7d. Orange lines refer to position of the seismic lines in Figs. 10a and 10b. Magenta lines refer to the position of the topograpahic profiles in (b); B: basement; ST: Sub-marine terraces; SPLF: slope parallel linear features; SD: subaqueous dunes. (b) Topographic profile (top), and corresponding slope gradient profile (bottom). D-D' and E-E' show the morphology of the continental shelf and the upper slope. F-F' show the evolution of the morphology morphology from west to east. G-G' show the morphology of the step on the east flank of the Rast Tarf promontory. H-H' show the morphology of sub-aqueous dunes. The light purple patches indicate the positions of the ledges, L; the pink patches indicate the position of ST1; the green patches indicate the position of ST2; the light orange patches the position of ST3. 


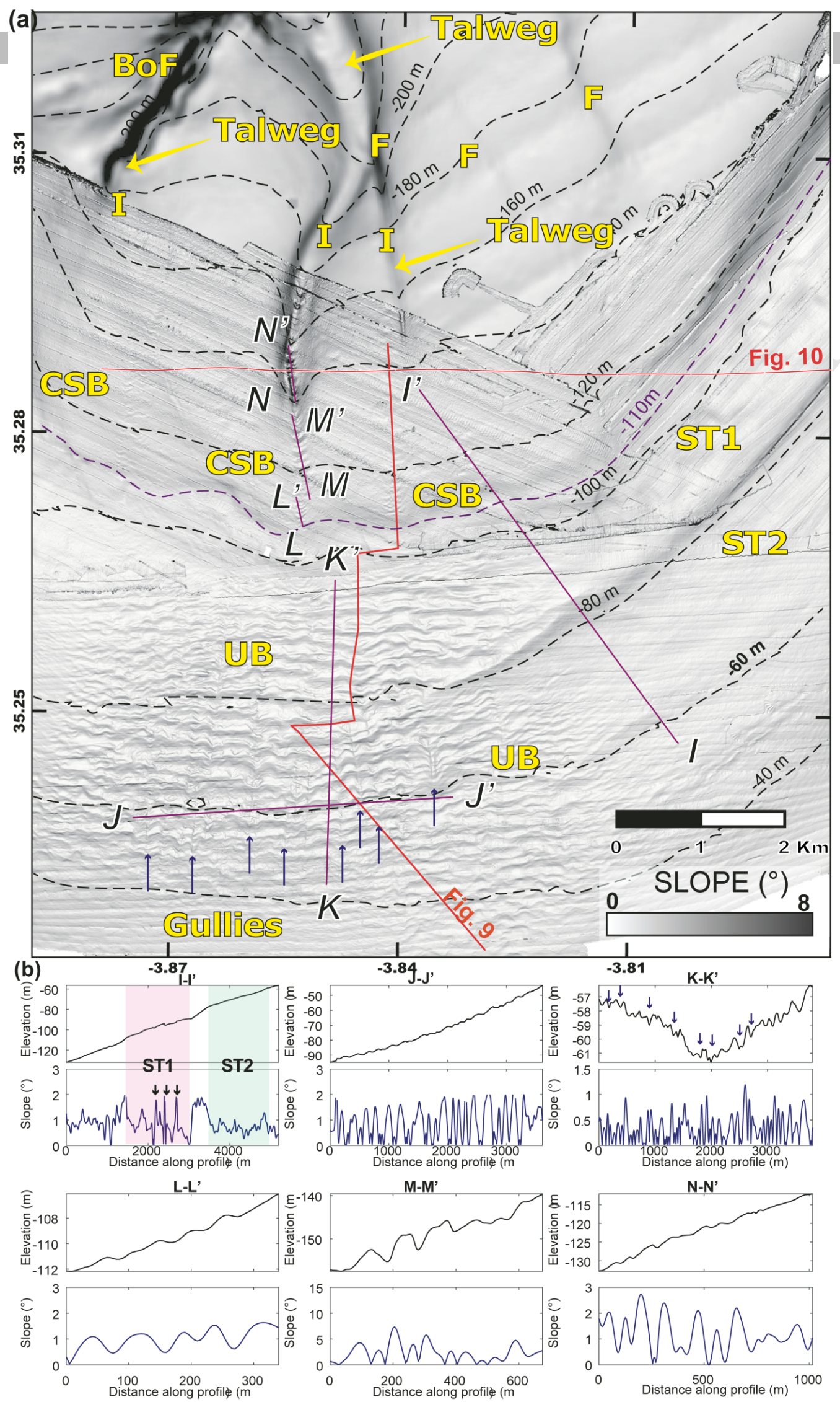

Figure 6. (a) Slope map and isobaths of the central sector of the shelf (Nekor basin) showing the morphological and structural features. BoF: Bokkoya fault; F: faults; I: Incisions; CSB: crescent shaped bedforms; U: undulated bedforms; ST: sub-marine terraces; Orange lines refer to position of the seismic lines in Figs. 8 and 9. Magenta lines refer to the position of the topographic profiles in (b); the blue arrows point to the heads of the gullies. (b) Topographic profile (top), and corresponding slope gradient profile (bottom). The topographic profiles I-I' show the morphology of the terraces in the continental shelf; the black arrows on

the slope gradient curve indicate artefacts linked to the multibeam acquisition. J-J' show the morphology of the undulated bedforms; K-K' show the morphology of the gullies; the position of the gullies are indicated by the blue arrows. L-L' to N-N' profiles show the morphology of the CBS below the shelf break. The pink patch indicates the position of ST1, and the green patch the position of ST2. 


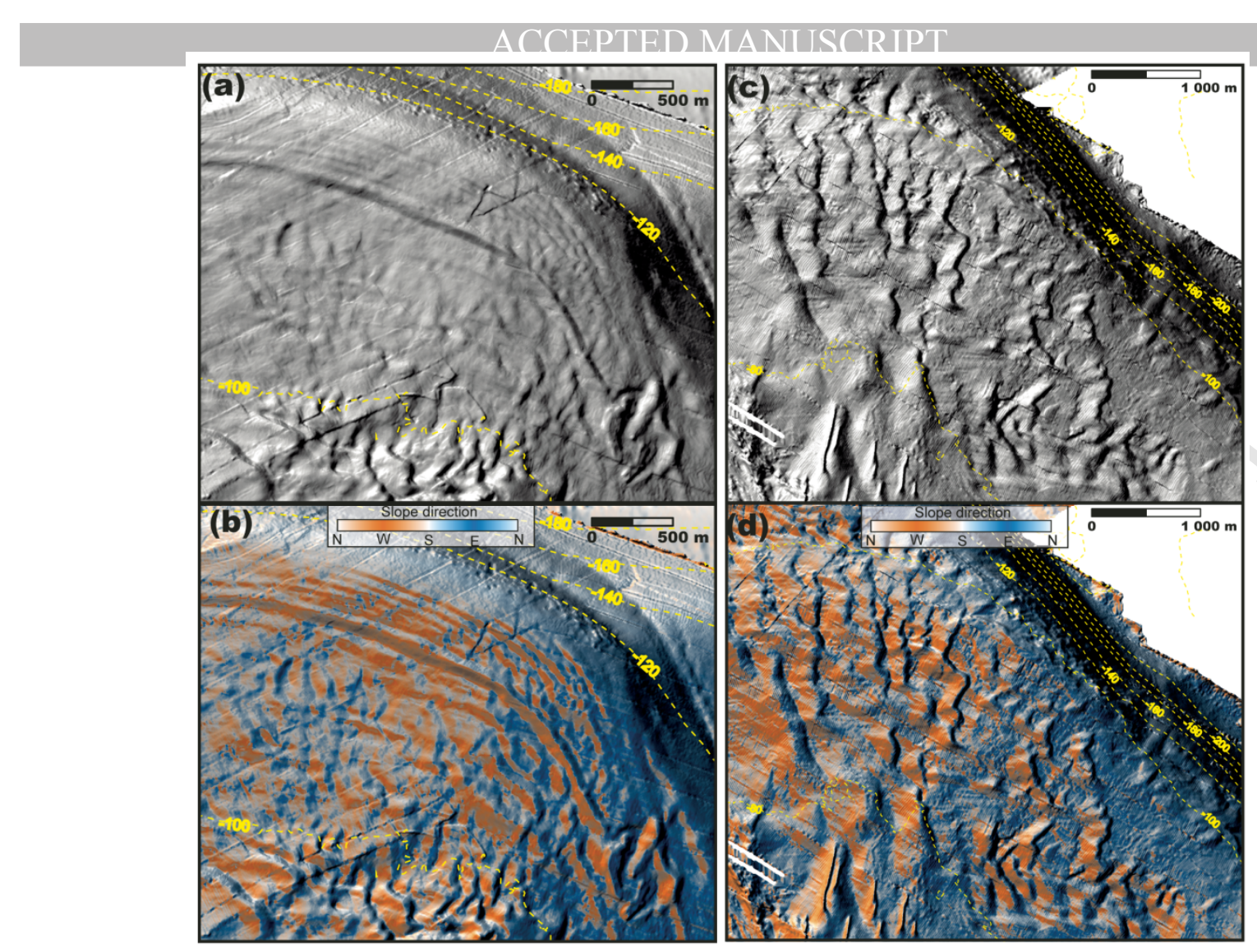

Figure 7. Morphology of the sub-aqueous dunes and shelf edges in the two sectors of the Morocco continental shelf. (a) and (b) Shaded bathymetry and slope direction maps in the Ras El Abid sector displaying collapsed sub-aqueous dunes over the submarine terrace on the outer shelf. (c) and (d) Shaded bathymetry and slope direction maps in the Ras Tarf sector displaying collapsed sub-aqueous dunes over the sub-marine terrace in the outer shelf. Contour lines every $20 \mathrm{~m}$. The Shelf parallel linear features in (a) and (b) are located at the shelf edge and limit the north extend of the dune field. Note the differences of height bewteen the dunes in (a) and (b) compared to (c) and (d). 


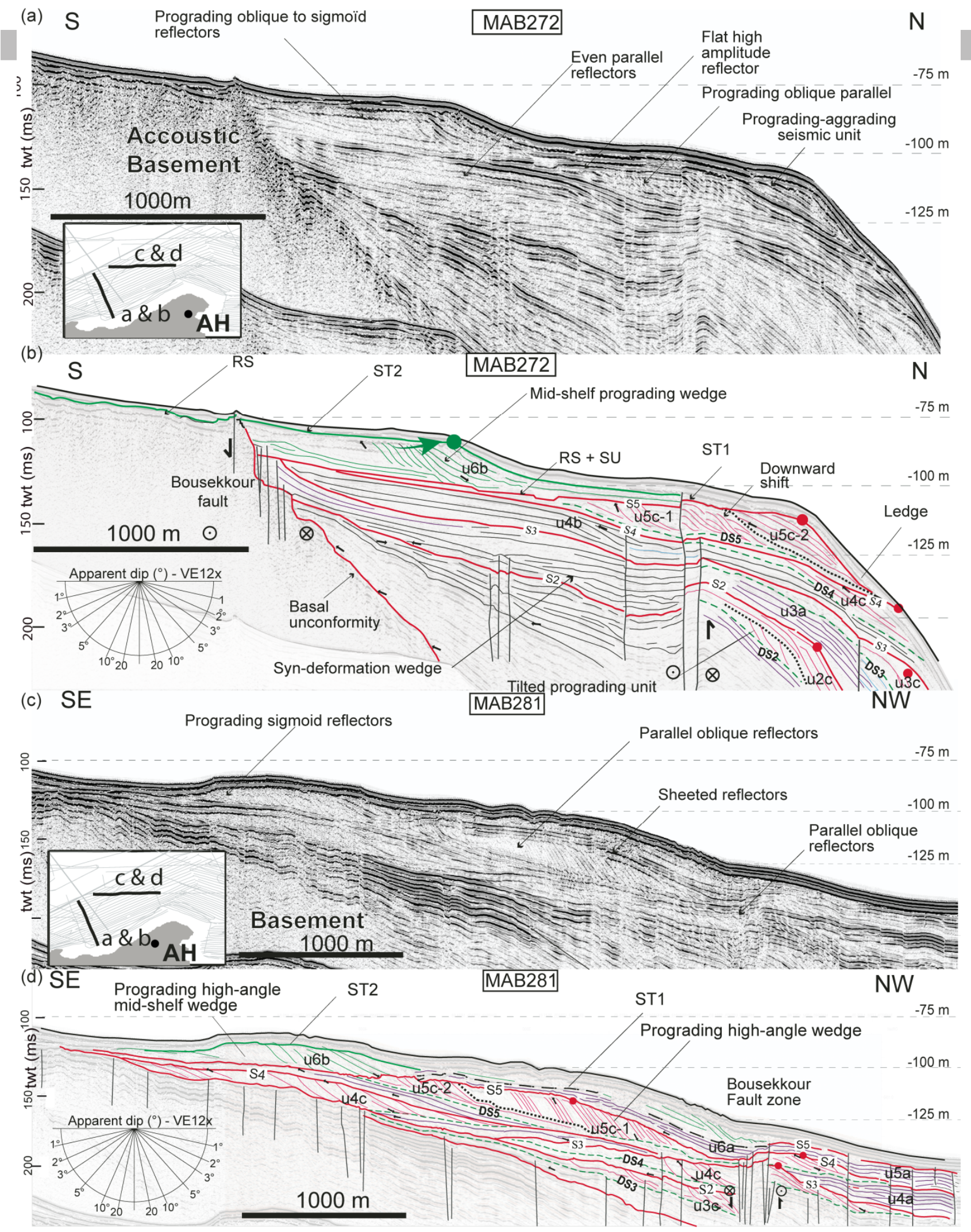




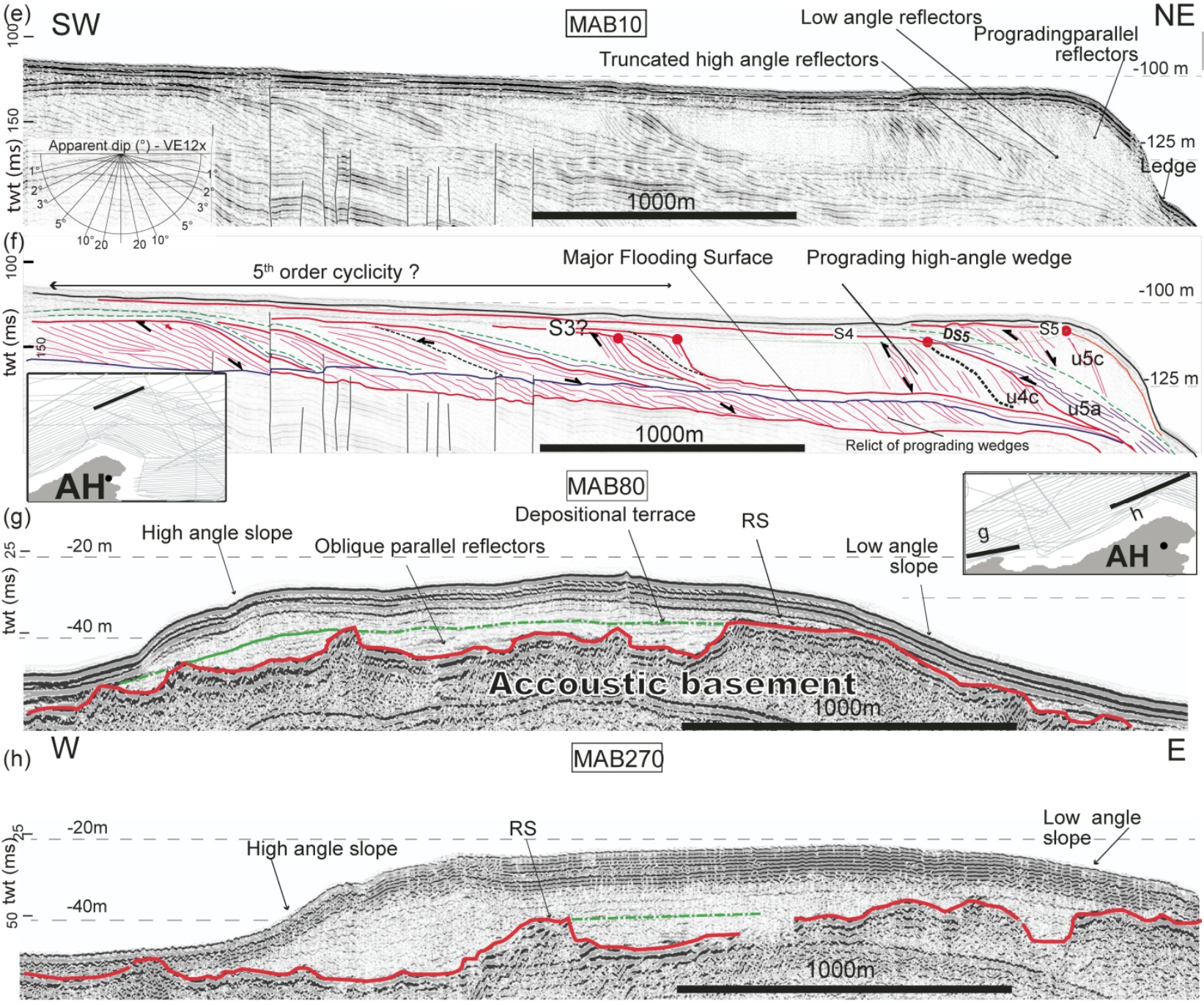

Figure 8. Selected seismic profiles showing the stratigraphic architecture of the western sector, in the hanging wall of the Bousekkour fault and in the Ral El Abid. (a) and( b) MAB272 seismic profile and the corresponding line drawing. (c) and (d)

MAB281 seismic profile and the corresponding line drawing. (e) and f) MAB10 seismic profile and the corresponding line drawing. Selected seismic profiles displaying the inner shelf wedges in the Bousekkour continental shelf. (g) MAB80 seismic profile. (g) MAB 270 seismic profile. Insets: positions of the seismic section and vertical exaggeration. Grey surface: emerged areas; AH: Al-Hoceima. On all the seismic lines, vertical exaggeration (VE) for the water column was computed using a P-wave velocity in the water of $1,510 \mathrm{~m} / \mathrm{s}$. The apparent dips of the reflector were computed in accordance with the vertical exaggeration.

Red lines S2 to S5 refer to regional unconformities. Dashed green line to downlap surfaces DS1 to DS5; Dashed black line to local unconformity below and above the S and DS surfaces, respectively; black dotted dashed line to local unconformity above and below the S and DS surfaces, respectively; green line, toplap surface of u6b; dashed dotted green line, angular unconformity; purple reflectors refer to distal aggrading wedges; pink reflectors refer to prograding high angle wedge; light blue reflectors refer to low angle prograding wedge; light green reflectors refer to mid-shelf prograding high angle wedge. RS: ravinement surface; SU: subaerial unconformity; ST: sub-marine terrace; thick blue-red line, local downlap surface; vertical black lines: faults; red dot: offlap break; green arrow: offlap break trajectory. Note that the faults appear sub-vertical due to the vertical exaggeration. 


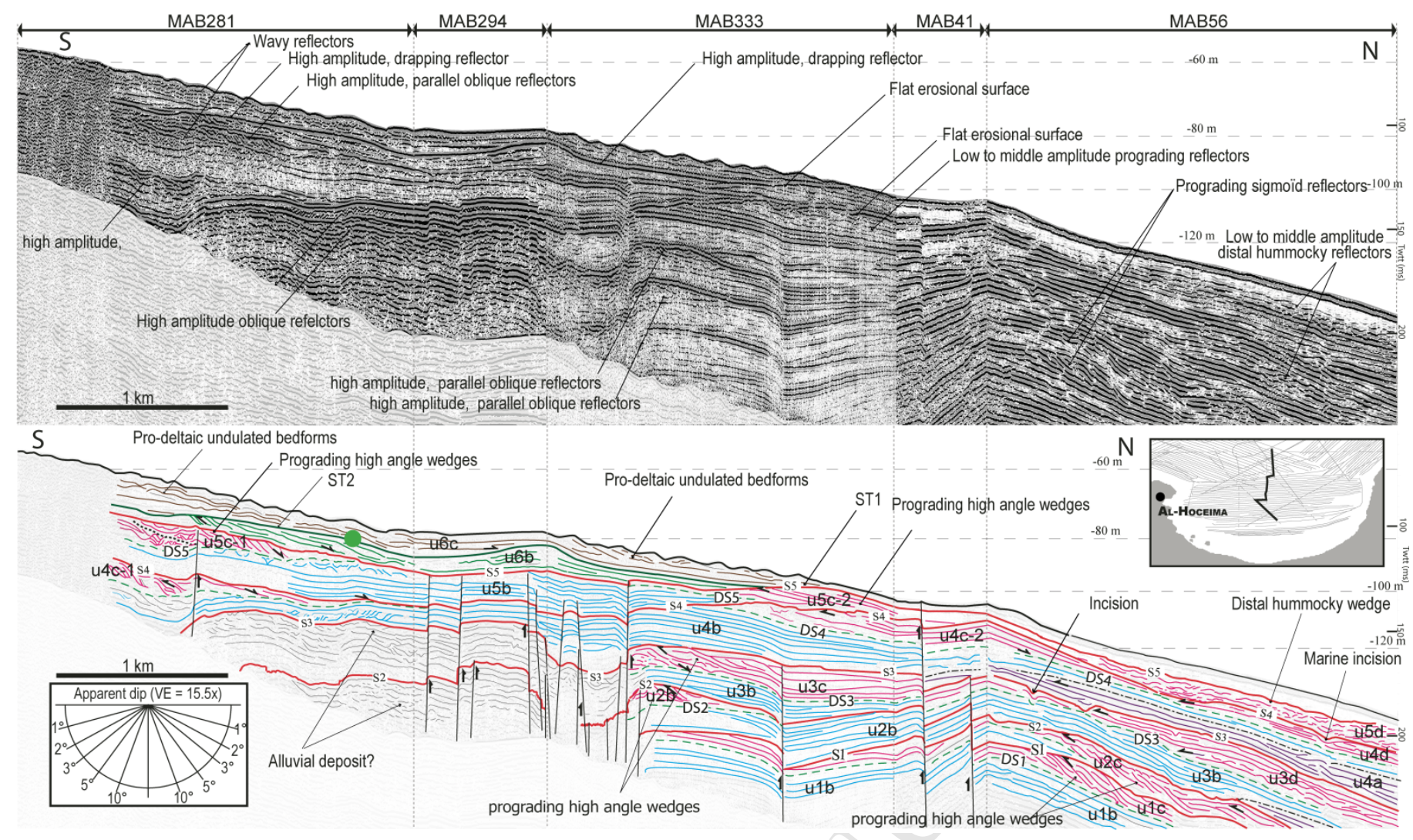

Figure 9. Composite seismic profile showing the seismic architecture of the central sector of the continental shelf and slope. (a) and (b) Un-interpreted composite profile and the corresponding line drawing. Insets: positions of the seismic section and vertical exaggeration. Grey surface: emerged areas; red lines S1 to S5 refer to regional unconformities; dashed green line: downlap surfaces DS1 to DS5; dashed black line: local unconformity below and above the S and DS surfaces, respectively; black dotted dashed line to local unconformity above and below the S and DS surfaces, respectively; green line, toplap surface of u6b; purple reflectors refer to distal aggrading wedges; pink reflectors refer to prograding high angle wedge on the continental shelf and to distal hummocky wedge on the upper slope; light blue reflectors refer to low angle prograding wedge; light green reflectors refer to mid-shelf prograding high angle wedge; brown reflectors refer to wavy mid-shelf wedge. S: ravinement surface; SU: Subaerial unconformity; ST: sub-marine terrace; vertical black lines, faults; red dot: offlap break; green dot, offlap break of the seismic subunit $\mathrm{u} 6 \mathrm{~b}$. Note that the faults appear sub-vertical due to the vertical exaggeration. 